\title{
Review \\ Global Mangrove Deforestation and Its Interacting Social-Eco- logical Drivers: A Systematic Review and Synthesis
}

\author{
Avit K. Bhowmik ${ }^{1,2, a, *}$, Rajchandar Padmanaban ${ }^{3,4, a}$, Pedro Cabral ${ }^{3}$ and Maria M. Romeiras ${ }^{5}$ \\ 1 Risk and Environmental Studies, Karlstad University, Universitetsgatan 2, SE 65188 Karlstad, Sweden \\ 2 Centre for Research on Sustainable Societal Transformation (CRS), Karlstad University, Universitetsgatan 2, \\ SE 65188 Karlstad, Sweden \\ 3 NOVA IMS, Universidade Nova de Lisboa, 1070-312 Lisbon, Portugal \\ 4 Centro de Estudos Geográficos, Instituto de Geografia e Ordenamento do Território, Edificio I, \\ Universidade de Lisboa, R. Branca Edmée Marques, 1600-276 Lisboa, Portugal \\ 5 LEAF, Linking Landscape, Environment, Agriculture and Food, Instituto Superior de Agronomia (ISA), \\ Universidade de Lisboa, Tapada da Ajuda, 1349-017 Lisbon, Portugal \\ a These authors have contributed equally \\ * Correspondence: avit.bhowmik@kau.se; Tel.: 0046547001044
}

\begin{abstract}
Globally mangrove forests are substantially declining and a globally synthesized database of the drivers of deforestation and drivers' interaction is scarce. Here we synthesized the key socialecological drivers of global mangrove deforestation by reviewing about two hundred published scientific studies over the last four decades (from 1980 to 2021). Our focus was on both natural and anthropogenic drivers with gradual and abrupt impacts and their geographic ranges of effects and how these drivers interact. We also summarized the patterns of global mangrove coverage decline between 1990 and 2020 and identified the threatened mangrove species and their geographic ranges. Our consolidated studies reported a $8,600 \mathrm{~km}^{2}$ decline in the global mangrove coverage between 1990 and 2020 with the highest decline occurring in South and Southeast Asia $\left(3870 \mathrm{~km}^{2}\right)$. We could identify 11 threatened mangrove species, two of which are critically endangered (Sonneratia griffithii and Bruguiera hainseii). Our reviewed studies pointed to aquaculture and agriculture as the predominant driver of global mangrove deforestation though the spatial distribution of their impacts varied. Gradual climate variations, i.e. seal-level rise, long-term precipitation and temperature changes and driven coastline erosion, constitute the second major group of drivers. Our findings underline a strong interaction across natural and anthropogenic drivers with the strongest interaction between the driver groups aquaculture and agriculture and industrialization and pollution. Our results suggest prioritizing globally coordinated empirical studies linking drivers and mangrove changes and a global development of policies for mangrove conservation.
\end{abstract}

Keywords: Mangroves; Driver; Anthropogenic activities; Climate change; Extreme events; Wetlands; Interaction

\section{Introduction}

The tropical, subtropical and warm temperate climate regions of the world comprise intertidal mangrove forests forming an unique interface between terrestrial and marine ecosystems with enriched biodiversity composed of different species of flora and fauna, upon which millions of people depend on [1-3]. Mangroves provide unique and valuable ecosystem services, i.e. provisioning (e.g. aquaculture, fisheries, fuel, medicine, textiles), regulating (e.g. shoreline protection, erosion control, climate regulation), intermediate (nutrient cycling, nursery habitat), and cultural (recreation and tourism) [4-7]. Moreover, about $10-15 \%$ of coastal sediment retention and carbon storage are globally driven by the mangrove forests [8]. These values are five times greater per hectare $\left(0.01 \mathrm{~km}^{2}\right)$ than those driven by tropical forests and other coastal wetlands together [9]. Mangrove forests also 
act as an important environmental barrier between shores and lands, protecting the inhabiting communities from the adverse impacts of extreme events, such as hurricanes and storms worldwide $[5,10]$.

In spite of their critical contribution to human and ecosystem welfare, mangrove forests have been declining globally at an alarming rate during the past 40 years [11-13]. The severity of the mangrove deforestation has also been manifested in the substantial mangrove habitats, species and ecosystem services losses [14]. For example, during the last 75 years, Philippines has lost more than $75 \%$ of its mangrove forests, with more than $66 \%$ lost only since 1990 [15]. In Africa, which accounts for about 20\% of global mangrove forests, $63 \mathrm{~km}^{2}$ have been lost during 2005, dominantly in West Africa, e.g. in Gabon, Sierra Leone, Guinea-Bissau and Senegal [16]. Approximately 70 plant species that comprise global mangrove forests and are frequently used as indicators for coastal changes due to their specialized adaptation and minor variation across hydrological and tidal regimes, are on a noticeable decay [17]. Several mangrove species in Southeast Asia, e.g. Aegiceras floridum (with a native range from Malesia to New Guinea) [18], Camptostemon philippinensis (native range in Philippines) [19], Heritiera globose (native to Borneo) [20], and Kandelia candel (native to Asia-Tropical) [21] are now endemic.

The mangrove deforestation is subject to a multitude of social-ecological drivers, ranging from climate change and natural perturbations to pollution and anthropogenic exploitation of mangrove resources [22-24]. Two main groups of drivers emerged in recent studies:

- Environmental drivers such as climatic and associated geological changes [10], e.g. increased salinity driven by increasing temperatures [25], and natural disasters, e.g. tropical cyclones [26] and tsunamis [27]; and

- Anthropogenic activities, e.g. aquaculture and agriculture, in situ encroachment [28], exploitation of forest resources [29], water withdrawal [30], urbanization [31] and pollution in upstream [32].

Among these, tropical cyclones entailed disruptive temporary damages from which mangrove forests may or may not recover, whereas climatic changes and anthropogenic activities cause gradual and largely irreversible loss of mangrove forests [33]. Climate and related changes, e.g. changes in thermal regimes and sea-level rise, emerged as a dominant environmental driver of mangrove deforestation [34]. Sea-level has been indicated as the most important factor influencing the future distribution of mangroves while the mangrove ranges may shift further Northward and Southward as an effect of global warming and shift in thermal regimes [34]. As the frequency of the occurrences of tropical cyclones increased with the global warming and resulting climate change, mangrove responses to tropical cyclones and their regeneration patterns also altered [35-37]. Availability of sediments was identified as a crucial supporting factor for the regeneration of minerogenic mangroves from the cyclone aftermaths [6]. Among the anthropogenic drivers, land changes and encroachment were augmented in the Southeast Asia as a result of aquaculture and agriculture expansions, e.g. shrimp aquacultures and palm plantations [38,39]. Coastal development and urbanizations also drove a major decline in mangrove coverage, particularly in the Asian, Caribbean and Sub-Saharan regions [39-41].

The environmental and anthropogenic drivers may interact in a complex web and may exacerbate the rate of mangrove deforestation [42,43]. For example, salinity intrusion, which is an environmental driver of deforestation of the coastal mangrove belts in several regions, may be mediated and amplified by complex interaction among geographical location, flow modifications in upstream, costal embankments, sea level rise, cyclone and storm surge, brackish water effect, precipitation and shrimp aquaculture [17,44-47]. Global conservation and management efforts like "Global Mangrove Alliance" [11] require a global level synthesis and consolidation of these drivers of mangrove deforestation as well as an understanding of their complex interactions. 
Recently published articles studying global mangrove deforestation and drivers either focused on a subset of global mangrove areas [48] or a subset of drivers [1,31] and did not study the interaction among drivers $[13,49]$. In this review, we draw on scientific literature and synthesize the social-ecological drivers of mangrove deforestation at a global level. The deforestation of mangrove forests covers both total and permanent deforestation such as loss in mangrove coverage as well as partial and temporary deforestation such as defoliation and damages caused by cyclones. We start by analyzing the changes in the geographic distribution of mangrove forest coverage and subsequently assess the current status of the mangrove species. The drivers of mangrove forests deforestation are then identified along with their geographic ranges of effects. Our review ends with an analysis of the interactions among the drivers and a discussion on the challenges involved in mangrove forest conservation.

\section{Methods}

Two electronic scientific literature sources, i.e. Web of Science (webofknowledge.com) and Scopus (www.scopus.com), were accessed between 2017 and 2021 to search for original articles, commentaries, books, letters and reports related to mangrove deforestation. We searched across all literature that were published between $1^{\text {st }}$ January 1980 and $28^{\text {th }}$ February 2021 using the initial keywords: "mangrove distribution", "mangrove biomass", "mangrove species" and "mangrove ecosystems" to identify literature that studied mangrove forests in general (Table 1). We then excluded literature that either did not study changes and deforestation of mangroves or did not address the drivers of changes. A total of 250 scientific literature sources were found, which were further filtered using three sets of keywords based on a priori knowledge of drivers of global mangrove deforestation (Table 1). The first keyword set "Climate" included drivers related to the long-term gradual changes in temperature, precipitation and sea level rise. The keyword set "Extreme events" involved extreme events like cyclones and Tsunamis. "Land changes" indicated a set of anthropogenic drivers and included search terms related to agriculture and aquaculture expansion and urbanizations, while pollution aspects such as heavy metal contamination were included in the "Pollution" set. Finally, the "Flow modification" set included drivers related to the diversion of surface water flow and their impacts on the mangrove forests. The returned search records included at least one entry from each of the four keyword sets. We obtained further inputs from subject experts to revise the search strategy and also to locate additional literature. Thus, we arrived at a final set of 201 scientific literature for the analyses and synthesis of this review.

Table 1. List of the combination of keywords and keyword sets, and the number of literature obtained.

\begin{tabular}{|c|c|c|c|c|}
\hline \multirow[t]{2}{*}{ Initial keywords } & \multirow{2}{*}{$\begin{array}{l}\text { Driver related key- } \\
\text { word sets }\end{array}$} & \multicolumn{3}{|c|}{ Number of literature } \\
\hline & & WOS & Scopus & Total \\
\hline \multirow{6}{*}{$\begin{array}{l}\text { \{mangrove distribu- } \\
\text { tion, mangrove bio- } \\
\text { mass, mangrove spe- } \\
\text { cies, mangrove eco- } \\
\text { systems\} }\end{array}$} & Climate & 15 & 14 & 29 \\
\hline & Extreme events & 20 & 25 & 45 \\
\hline & Land changes & 29 & 25 & 54 \\
\hline & Pollution & 12 & 15 & 27 \\
\hline & Flow modification & 16 & 30 & 46 \\
\hline & Total & 92 & 109 & 201 \\
\hline
\end{tabular}

To assess the change in mangrove forest coverage and the current status of the mangrove species, we linked the consolidated literature with four online databases on mangrove forests distribution and species: a) Global Mangrove Watch (GMA: https://www.globalmangrovewatch.org/), b) the mangrove species occurrence dataset of 
Global Biodiversity Information Facility (GBIF: https://www.gbif.org), c) the native distribution dataset of Plants of the World Online (POWO: www.plantsoftheworldonline.org), and d) International Union for Conservation of Nature (IUCN) Red List of Threatened Species (www.iucnredlist.org).

We first examined the change in the global mangrove forests coverage during the period represented by the consolidated literature. We found 36 studies that consistently reported mangrove forests coverage across five global mangrove regions and three decades between 1990 and 2020 (see Table 2 for details). The reported area coverage values for mangrove forests were checked against the GMA datasets and compared to calculate the change in the coverage of global mangrove forests. Subsequently, we identified the vulnerable and endangered mangrove species from the IUCN database and their occurrence and native distribution from the GBIF and POWO databases. This information was cross-checked using the consolidated literature. We mapped the status of the mangrove species across the United Nations Food and Agriculture Organization (FAO) delineated marine fishing areas [50] using QGIS v.3.4.4 (see Figure 1), as these provide the most detailed account of the coastal wetland and mangrove species. In the third step, we identified and grouped the drivers of mangrove forest deforestation and identified their impacts on mangrove habitats, species, ecosystems and societies in general, and also examined their geographic ranges of effects (Figure 2, Table 3). For each driver and driver group, interacting drivers and driver groups were also identified when reported by the consolidated literature. Finally, the interactions among the drivers were mapped using a ChordDependency Diagram (Figure 3).

Table 2. Mangrove coverage in global regions and the decline in coverage between 1990 and 2020.

\begin{tabular}{|c|c|c|c|c|c|c|c|}
\hline \multirow[t]{2}{*}{ Global regions } & \multicolumn{4}{|c|}{$\begin{array}{c}\text { Mangrove coverage } \\
\text { km² }^{2}\end{array}$} & \multicolumn{3}{|c|}{$\begin{array}{c}\text { Rate of decline } \\
\% / \text { year }\end{array}$} \\
\hline & 1990 & 2000 & 2010 & 2020 & $\begin{array}{l}1990- \\
2000\end{array}$ & $\begin{array}{l}2000- \\
2010\end{array}$ & $\begin{array}{r}2010- \\
2020\end{array}$ \\
\hline Western \& Central Africa & 24,360 & 24,200 & 23,890 & 23,840 & 0.07 & 0.13 & 0.02 \\
\hline Eastern \& Southern Africa & 9,290 & 9,050 & 9,020 & 8,830 & 0.26 & 0.03 & 0.21 \\
\hline Total Africa & 33,650 & 33,250 & 32,910 & 32,670 & 0.12 & 0.10 & 0.07 \\
\hline East Asia & 320 & 250 & 240 & 220 & 2.19 & 0.40 & 0.83 \\
\hline South \& Southeast Asia & 57,170 & 57,080 & 55,130 & 53,300 & 0.02 & 0.34 & 0.33 \\
\hline Western \& Central Asia & 1,900 & 1,900 & 1,900 & 1,840 & 0.00 & 0.00 & 0.32 \\
\hline Total Asia & 59,390 & 59,230 & 57,270 & 55,360 & 0.03 & 0.33 & 0.33 \\
\hline Caribbean & 7,910 & 7,890 & 7,870 & 7,740 & 0.03 & 0.03 & 0.17 \\
\hline Central America & 4,920 & 4,830 & 4,820 & 4,660 & 0.18 & 0.02 & 0.33 \\
\hline North America & 11,950 & 11,900 & 11,670 & 11,520 & 0.04 & 0.19 & 0.13 \\
\hline Total Caribbean, Central and North America & 24,780 & 24,620 & 24,360 & 23,920 & 0.06 & 0.11 & 0.18 \\
\hline Total Oceania & 12,470 & 12,140 & 11,550 & 11,500 & 0.26 & 0.49 & 0.04 \\
\hline Total South America & 21,520 & 21,240 & 20,500 & 19,760 & 0.13 & 0.35 & 0.36 \\
\hline World & 151,810 & 150,480 & 146,590 & 143,210 & 0.09 & 0.26 & 0.23 \\
\hline
\end{tabular}

\section{Changes in mangrove forests coverage}

Our consolidated literature (36) that reported changes in the mangrove forests coverage covered three decades, i.e. between 1990 and 2020 and about all of the global mangrove forests [49,51] (see Table 2 for details). The mangrove belts are largely found in the 
equatorial coastal regions with the tropical, sub-tropical and warm temperate climate between $30^{\circ} \mathrm{N}$ and $30^{\circ} \mathrm{S}[11,52]$. Mangroves typically grow in harsh environment with moderate to high temperatures, tidal fluctuations and high salinity in groundwater [53,54]. These conditions nourish canopies of mangrove growth up to $30-40 \mathrm{~m}$ in height [55]. The majority of mangrove forests (about $40 \%$ ) covers only 4 countries, i.e. Indonesia, Australia, Brazil and Mexico with the Asian region holding the largest (around $42 \%$ ) and most diverse mangrove areas [12,39]. About $15 \%$ of the mangrove forests is situated in Africa, while Oceania and South America cover $12 \%$ and $11 \%$ of the global mangrove forests, respectively [56,57]. Ramsar wetlands (the Sundarbans in Bangladesh and India, Garig Gunak Barlu in Australia, Cayapas-Mataje in Ecuador, Everglades in the United States and Douala Edea in Cameroon) had a mangrove coverage of about $378,960 \mathrm{~km}^{2}$ in 2020 $[11,58,59]$.

The studied mangrove forests by our consolidated literature exhibited an overall decline of more than 5\% in global coverage between 1990 and 2020 [11,39,49,60] (Table 2). Globally, the mangrove cover declined by $8600 \mathrm{~km}^{2}$ between 1900 and 2020 (Table 2) at a rate of $287 \mathrm{~km}^{2}$ per year ( Mangrove Alliance 2020). 60\% of the literature that reported changes in the mangrove forests distribution studied countries in the South and Southeast Asian region, which experienced the highest mangrove loss $\left(3870 \mathrm{~km}^{2}\right.$ and more than $6 \%$ decline in the coverage) between 1990 and 2020 [11,59,62,63]. The mangrove habitat loss in South and Southeast Asia was recorded at an average rate of $0.34 \%$ and $0.33 \%$ per year between 2000 and 2010 and between 2010 and 2020, respectively, which are also the highest among the mangrove regions globally $[12,31,64]$. The mangrove habitat loss in South America followed a similar average rate of $0.30 \%$ and $0.31 \%$ per year between 2000 and 2010 and between 2010 and 2020, respectively $[11,12,65]$. The total areal loss of mangrove forests in South America is $1360 \mathrm{~km}^{2}$ between 1990 and 2020 while $3937 \mathrm{~km}^{2}$ was lost in Asia (Table 2). Among the Asian countries, Indonesia encountered the highest areal loss $\left(\right.$ more than $700 \mathrm{~km}^{2}$ ) [38], while Malaysia experienced highest loss in percentage (more than 3\%) [66] between 2000 and 2010. Mangrove forests in Ramsar sites also encountered substantial losses (5\% of the global coverage) between 2000 and 2010 [58].

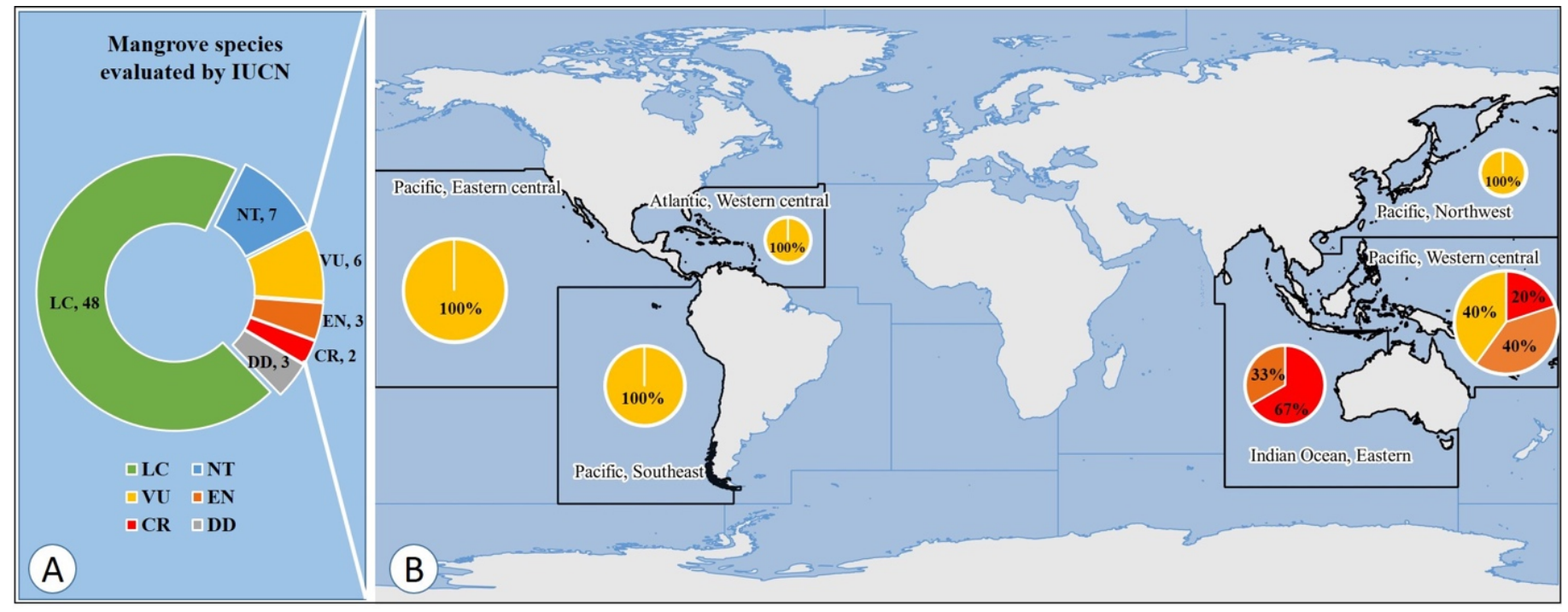

Figure 1. Geographic ranges of the threatened mangrove species (LC: Least Concern; VU: Vulnerable; CR: Critically Endangered; NT: Not Threatened; EN: Endangered; DD: Data Deficient).

\section{Status of the mangrove species}


Our consolidated literature reported the status of 69 mangrove plant species $[67,68]$, 35 of which have their native ranges in the Philippines [69,70]. Among the reported mangrove plant species, 11 are listed as threatened (2 as Critically Endangered "CR", 3 as Endangered "EN" and 6 as Vulnerable "VU") (Figure 1). The geographic ranges of the $5 \mathrm{CR}$ and EN mangrove species are dominantly Southeast Asia (Figure 1). Among the CR species, Sonneratia griffithii (Lythraceae) has a restricted distribution in South Asia, and is considered very rare or is locally extinct in many parts of its range [71]. Bruguiera hainesii (Rhizophoraceae), the other CR species, is very rare and has a limited and patchy distribution in Singapore, Malaysia and Papua New Guinea [71]. The three EN species (i.e. Camptostemon philippinense, Heritiera fomes and Heritiera globose, all from Malvaceae family) are very rare showing a patchy distribution in South Asia, particularly in areas impacted by ongoing coastal developments [70-72].

The VU mangrove plant group includes genera Avicennia and Rhizophora, which protect coastal areas from erosion, salt water intrusion, storms, high tides and floods $[53,73,74]$. The three VU Avicennia species (i.e. Avicennia bicolor; Avicennia rumphiana and Avicennia integra) have experienced severe decline during 1980 - 2005 in central America [68]. Avicennia bicolor, and three other VU mangrove species, i.e. Mora oleifera, Tabebuia palustris and Pelliciera rhizophorae, have their native distribution is in the Eastern Tropical Pacific ranging from Mexico to Colombia [68,71,75] (Figure 1).

The threatened mangroves species use to provide last refuge for several terrestrial animal species, like the yellow-shouldered blackbird (Agelaius xanthomus) and the Philippine cockatoo (Cacatua haematuropygia), which have now gone extinct $[62,76,77]$.

\section{Environmental drivers of mangrove deforestation}

Figure 2 provides a representation of the drivers of mangrove forest deforestation and its consequences which are explained in the following subsections. In Table 3, the environmental and anthropogenic drivers of mangrove deforestation and their geographic ranges of effects are presented.

\subsection{Climate change}

$79(39 \%)$ of our consolidated literature indicated climate change driven coastline erosion as a dominant environmental driver of mangrove deforestation (Table 3). Climate changes and impacts studied included alternations and variations in sea-levels, temperature regimes and precipitation patterns. These alternations were shown to impact the growth, recovery and spatial distribution patterns of the mangrove forests as well as to alter the composition of mangrove species [78]. The geographic ranges of climate change impacts covered almost all mangrove containing countries (Table 3). This section of the review provides a synthesis of the impacts of climate change on mangrove species and the past and future distribution of mangrove forests globally.

\subsubsection{Sea-level rise}

Sea-level rise was identified as an important driver of global mangrove deforestation by the literature studying the impacts of climate change [44,79,80]. Global warming driven melting of polar ice caps are projected to increase global sea level by $0.18-0.59 \mathrm{~m}$ between 2090-2099 [81]. This may lead to a retreat of the mangrove forest belts in low-lying coastal regions and small islands, e.g. Palembang (Indonesia), Sagar Island (India), Sundarbans (Bangladesh), Shenzhen (China) and Small Island States such as Solomon and Nuatambu [82-86]. For example, sea-level is rising at a rate of $3.14 \mathrm{~mm}$ per year (which may increase up to $3.5 \mathrm{~mm}$ per year) at the coast of Sagar Island, India, which has led to an approximate $0.4 \mathrm{~km}^{2}$ areal loss of mangrove forests between 2000 and 2015 [87]. 


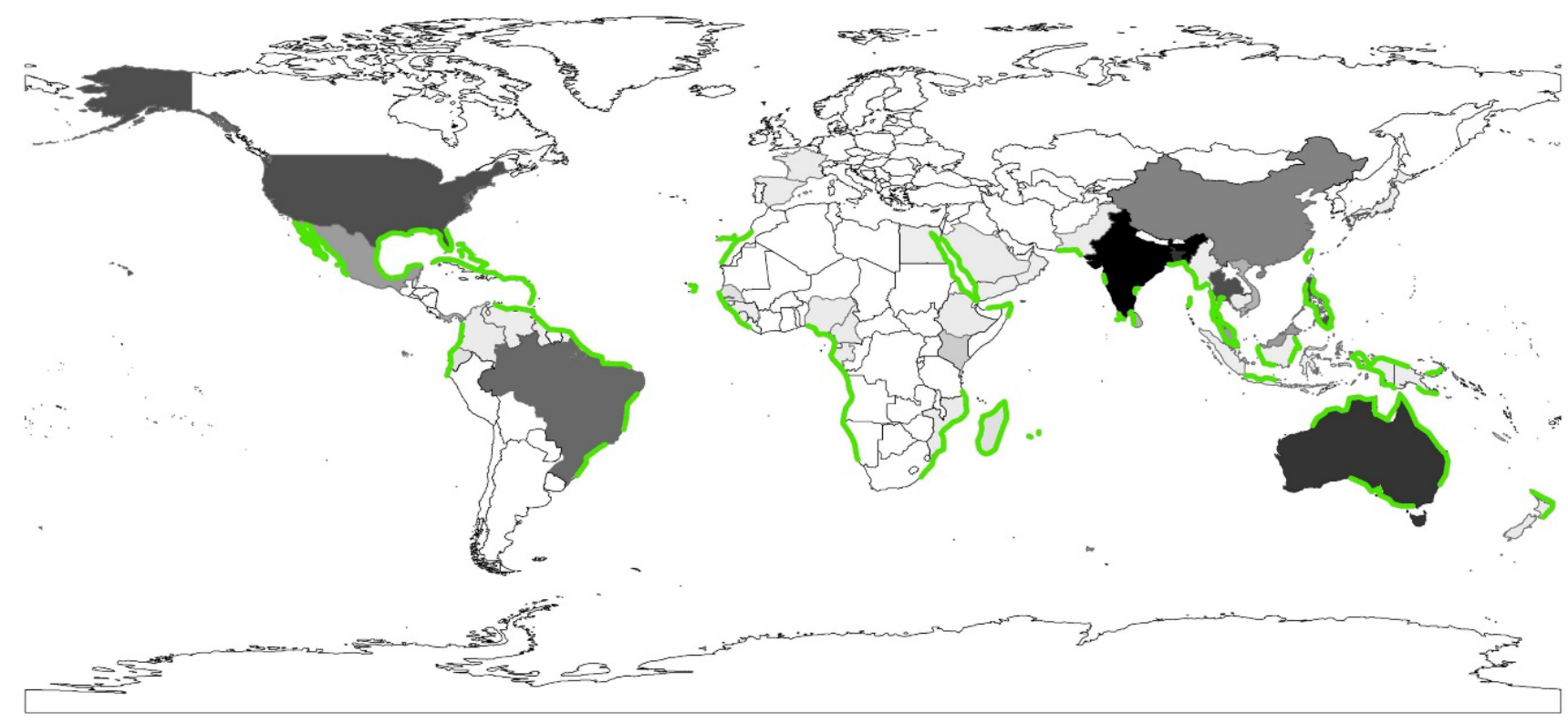

Number of papers

(a)

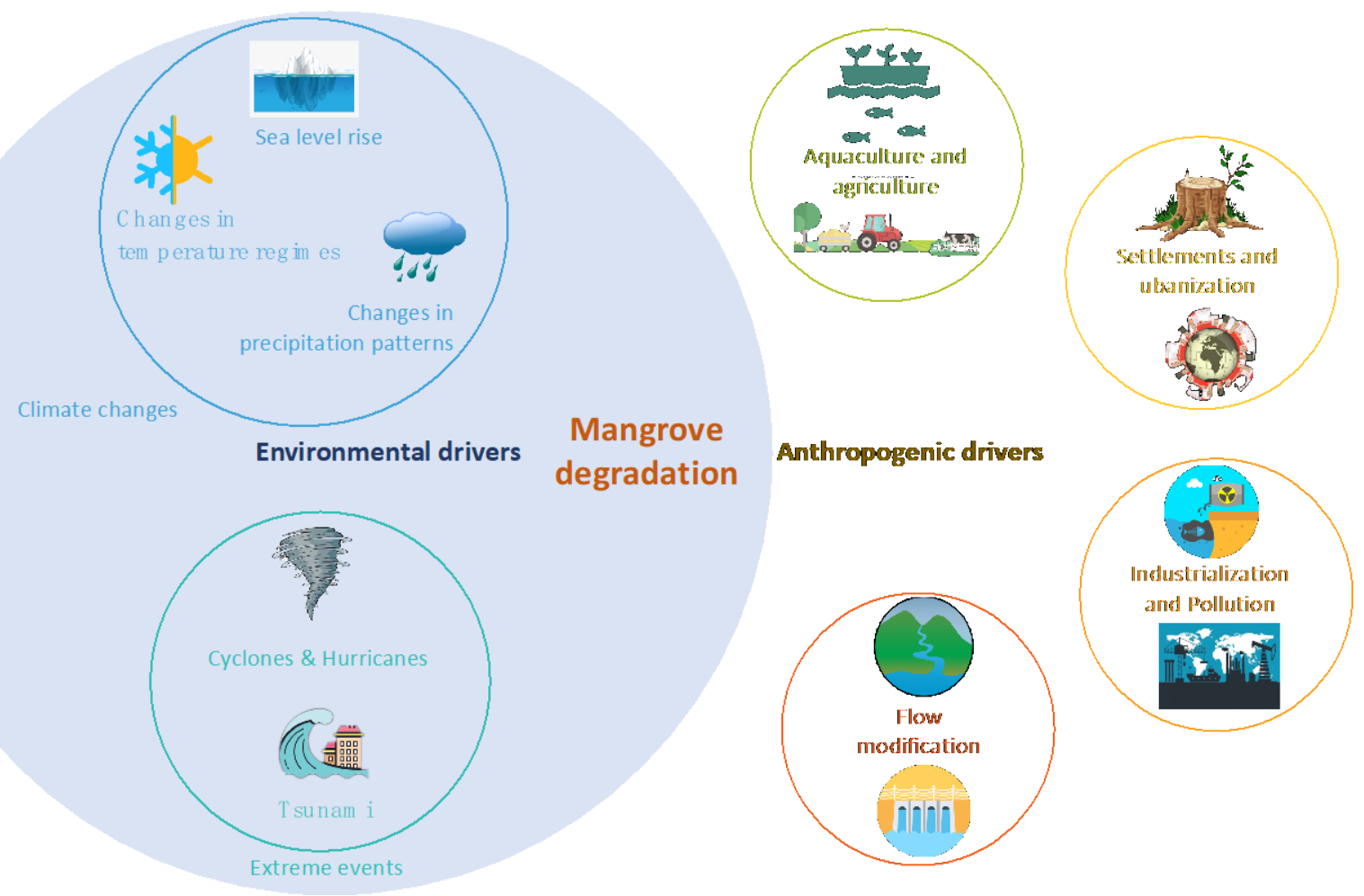

(b)

Figure 2. (a) Current global mangrove distribution (green stripe) and associated consolidated studies at the country level and (b) identified drivers and driver groups of mangrove deforestation. 
The effects of rising sea-level is mediated by the availability of the coastal wetland sediment surfaces for the minerogenic mangroves [88,89]. The availability of sediments often depend on the local tectonic progressions, erosion and other geological processes [90]. When the coastal sediment level and the rate of accretion are exceeded by the mean tide level as a result of sea-level rise, the minerogenic mangrove forest may encounter areal loss or even collapse [91].

The increase in sea-level can be coupled with extreme high water occurrences as a consequence of fluctuations in oceanic circulations, such as El Nino Southern Oscillation (ENSO)' [92] and 'Northern Atlantic Oscillation (NAO)' [93] and temperature regimes [94]. Such increase in the high water occurrences may further increase the mean tide level and impose coastal sediments to sulfide toxicity $[5,35]$.

\subsubsection{Changes in temperature regimes}

There has been an increase in global temperature by $0.74{ }^{\circ} \mathrm{C}$ between 1906 and 2005 with a doubled warming rate $\left(0.13^{\circ} \mathrm{C}\right.$ per decade) during the past five decades compared to the last 100 years average [95]. The warming could further accelerate ranging from about $0.2^{\circ} \mathrm{C}$ per decade to $0.4^{\circ} \mathrm{C}-0.8^{\circ} \mathrm{C}$ per decade if emissions reduction strategies fail and aerosols were to be rapidly removed [96].

Increased temperature affects mangroves by changing the ecosystems configuration and the species distribution as well as by reducing mangrove productivity rate and changing their phenological patterns [52]. For example, the mangrove canopy heights and biomasses depend on the regional temperature regime. An exceedance of this regional temperature regime threshold may decrease canopy growth by 1-2 $\mathrm{m}$ [97]. Summer heat waves, which are results of the global warming, drive habitat losses in the mangroves through defoliation and intense herbivory. For example, Hong Kong lost 22\% of the mangrove coverage during due to summer heat wave driven defoliation in the flowering seasons leading to low reproductivity and fewer seedlings [98]. Exceedance of the temperature tolerance regime may also drive extinction of mangrove species, as dominantly for the cases of Sonneratia griffithii and Bruguiera hainesii in the Southeast Asia [71].

"Hard freeze" (temperature region below $-3^{\circ} \mathrm{C}$ ) is a natural phenomenon in winter in the Southwest Florida, which managed the growth and expansion of the coastal mangrove forest [65]. With the decreasing hard freezes due to global warming, invasive plant species are advantaged and replacing mangrove species in this region [99]. Moreover, the sudden high temperature variations before and after the hard freezes slowed down the mangrove recovery process after the hard freezes [100]. However, the decreasing hard freezes and global warming, coupled with the sea-level rise, may also expand the mangrove belts towards the higher altitudes and thus entail a northward shift in the global mangrove belt [101].

\subsubsection{Changes in precipitation patterns}

Global warming will cause an increase of about $25 \%$ in average global precipitation by 2050 [102], although the regional patterns will vary, i.e. precipitation will increase in high latitudes whereas decrease in most subtropical countries that contains mangrove forests $[103,104]$. The decreased precipitation with amplified evaporation can lead to high salinity in the coastal wetland zones, which in turn may adversely affect mangrove productivity, development, sapling and seedling and thus shrink the coverage of mangrove forests, particularly where mangroves are already at their precipitation limits, e.g. arid zones of Africa and Central and South America [53,104,105]. The decreased precipitation may also drive a decline in groundwater table and reduce freshwater supply to mangroves, which exacerbate salinity intrusion in coastal wetlands and mangrove forests [104,106,107]. 
Table 2. Environmental and anthropogenic drivers of mangrove deforestation and their geographic ranges of effects. N/A - Not available.

Environmental drivers

\section{Climate changes}

\section{Countries}

(Sea-level rise, temperature and precipitation changes)

\begin{tabular}{|c|c|c|c|c|c|c|}
\hline Mexico & 5 & N/A & 3 & 5 & 1 & $\mathrm{~N} / \mathrm{A}$ \\
\hline Cuba & N/A & $\mathrm{N} / \mathrm{A}$ & 1 & 2 & 1 & N/A \\
\hline Brazil & 3 & $\mathrm{~N} / \mathrm{A}$ & 3 & 6 & 3 & 3 \\
\hline Guinea Bissau & 1 & 1 & $\mathrm{~N} / \mathrm{A}$ & 2 & $\mathrm{~N} / \mathrm{A}$ & N/A \\
\hline Guyana & N/A & $\mathrm{N} / \mathrm{A}$ & 2 & 2 & 1 & N/A \\
\hline Saudi Arabia & 1 & 1 & 1 & 4 & N/A & N/A \\
\hline Ethiopia & 2 & 1 & 4 & 3 & $\mathrm{~N} / \mathrm{A}$ & N/A \\
\hline Mozambique & 1 & $\mathrm{~N} / \mathrm{A}$ & 2 & 2 & 1 & $\mathrm{~N} / \mathrm{A}$ \\
\hline Madagascar & 4 & 2 & $\mathrm{~N} / \mathrm{A}$ & 2 & N/A & $\mathrm{N} / \mathrm{A}$ \\
\hline India & 9 & 4 & 6 & 11 & 7 & 4 \\
\hline Bangladesh & 6 & 4 & 6 & 8 & 2 & 3 \\
\hline Myanmar & 1 & 2 & $\mathrm{~N} / \mathrm{A}$ & $\mathrm{N} / \mathrm{A}$ & $\mathrm{N} / \mathrm{A}$ & $\mathrm{N} / \mathrm{A}$ \\
\hline Malaysia & 3 & $\mathrm{~N} / \mathrm{A}$ & 3 & 2 & N/A & $\mathrm{N} / \mathrm{A}$ \\
\hline Philippines & 6 & 2 & 6 & 1 & 1 & 1 \\
\hline Indonesia & 7 & 2 & 8 & 2 & 1 & 1 \\
\hline Australia & 3 & 4 & 1 & 6 & 2 & N/A \\
\hline Papua New Guinea & 1 & 1 & 1 & 1 & $\mathrm{~N} / \mathrm{A}$ & N/A \\
\hline New Zealand & 2 & 2 & 1 & 1 & $\mathrm{~N} / \mathrm{A}$ & $\mathrm{N} / \mathrm{A}$ \\
\hline Thailand & 4 & 2 & 6 & N/A & 1 & $\mathrm{~N} / \mathrm{A}$ \\
\hline Colombia & 3 & 2 & 1 & 1 & $\mathrm{~N} / \mathrm{A}$ & $\mathrm{N} / \mathrm{A}$ \\
\hline Nigeria & 2 & 2 & 1 & 2 & N/A & 1 \\
\hline Vietnam & 1 & 2 & 3 & 1 & $\mathrm{~N} / \mathrm{A}$ & $\mathrm{N} / \mathrm{A}$ \\
\hline China & 2 & N/A & 1 & 9 & 2 & 1 \\
\hline South Africa & 1 & N/A & $\mathrm{N} / \mathrm{A}$ & 4 & 2 & 1 \\
\hline Ecuador & N/A & N/A & 2 & N/A & 1 & $\mathrm{~N} / \mathrm{A}$ \\
\hline Pakistan & 1 & 2 & 2 & 4 & 1 & 3 \\
\hline Venezuela & 2 & N/A & $\mathrm{N} / \mathrm{A}$ & 1 & 1 & 1 \\
\hline United States & 2 & 4 & $\mathrm{~N} / \mathrm{A}$ & 3 & N/A & N/A \\
\hline Mauritius & 1 & 1 & $\mathrm{~N} / \mathrm{A}$ & 1 & 2 & 1 \\
\hline Sri Lanka & 2 & 2 & 1 & 6 & N/A & $\mathrm{N} / \mathrm{A}$ \\
\hline Kenya & 1 & 1 & $\mathrm{~N} / \mathrm{A}$ & 2 & 1 & $\mathrm{~N} / \mathrm{A}$ \\
\hline Japan & 2 & 3 & $\mathrm{~N} / \mathrm{A}$ & 4 & $\mathrm{~N} / \mathrm{A}$ & $\mathrm{N} / \mathrm{A}$ \\
\hline Total & 79 & 47 & 65 & 98 & 31 & 20 \\
\hline
\end{tabular}

\section{Anthropogenic drivers}

Extreme
events

\section{Aquaculture Settlements Industrializa-} and agricul- and Urbani- tion and Polture lution

Flow modification zation 
The increased precipitation in high latitudes coupled with the increasing sea-level may increase productivity and expand mangrove coverage towards the landward fringe of the tidal wetland zones [52]. The diversity of mangrove species may also increase as a result of an increased fluvial sand deposits and nutrients as well as abridged sulfate level and decreased salinity in the high latitudinal regions, e.g. South Florida [33]. However, heavy and flash precipitation can cause overflow of coastal waterbodies and introduce freshwater channels through the coastal uplands, which can transport sediments accumulated in downstream back upstream coastal areas. Such sediments overflow occurred in the Choluteca River of the Pacific coast of Honduras during Hurricane Mitch in 1998 [108] and in the Tijuana River in Southern California during the El Niño storm of 1993 [91], causing severe damage to the mangrove forests in these area [91].

\subsection{Extreme events}

The geographic location of the mangrove forests makes them particularly vulnerable to two groups of extreme events: (i) cyclones and hurricanes and (ii) Tsunamis [37]. According to the Intergovernmental Panel on Climate Change (IPCC), global warming resulted in the intensification of peak wind strength, tidal surge and precipitation resulted by the tropical cyclones and hurricanes along with an increase in their frequency of occurrences [109]. These impact mangrove forests temporarily through three primary means: sediment deposition, wind damage and submersion [35]. The intense winds lead to sudden and topple stems, defoliation of the canopies and damage of the mangrove tree branches [110]. Cyclones and hurricanes may also uproot mangrove trees through strong wind flow [111]. This may also affect soil stability and lead to soil erosion [91]. The long term impacts of cyclones on the mangroves are the decreased fertility rate, delayed seedling seasons and changes in coastal hydrology causing permanent ecosystem conversion [112]. Moreover, with the increased cyclone and hurricane frequencies, mangroves may lack the time required for recovery from the temporary damages and hence, may encounter permanent loss [63].

Damages of several mangrove regions by extreme events were noted by 47 (23\%) of our consolidated literature (Table 3). For example, Caribbean hurricane 'Joan' in 1988 caused $11 \%$ areal damage to the mangrove forests in Caribbean and Central America with reduced soil stability, permanent loss of several mangrove species and loss of forest density [113]. Sundarbans in Bangladesh and India - the world's largest mangrove forest region - has encountered a high frequency of tropical cyclones and tidal surge since the 1960s [114]. The Sundarbans encountered an areal damage of $2500 \mathrm{~km}^{2}$ by the tropical cyclone Sidr in 2007 [26]. Mangrove regions in Orissa and Tamilnadu in India experienced severe damages by several cyclones, e.g. the Super cyclone in 1999 [115], Vardah cyclone in 2016 [116], Ockhi cyclone in 2017 [117], and Gaja cyclone in 2018 [118].

Tsunamis have emerged as an environmental driver of mangrove deforestation leaving permanent damages to coastal mangrove ecosystems [119]. Particularly, the Great Tsunami of 2004, which originated in the Indian Ocean by an earthquake with the epicenter in Sumatra, Indonesia, on the Richter magnitude scale of $9.1-9.3$, led to a major 300 $\mathrm{km}^{2}$ areal loss of mangrove forests in 14 countries [120,121]. Indonesia encountered the largest loss (35\%) followed by India, Sri Lanka and Thailand. Andaman Island, India, Aceh Province, Sumatra and Andaman coast, Thailand lost approximately $38 \mathrm{~km}^{2}, 7.5 \mathrm{~km}^{2}$ and $3 \mathrm{~km}^{2}$ of mangrove forest coverage as a result of this Tsunami, respectively [122-124]. Tsunami driven mangrove cover and habitat losses were also observed later in Japan in 2011 and Papua New Guinea in 1999 [119,125,126]. 


\section{Anthropogenic drivers of mangrove deforestation}

\subsection{Aquaculture and agriculture}

Aquaculture and agriculture were identified as the most dominant driver of global mangrove deforestation in our consolidated literature accounting for approximately $47 \%$ of the global mangrove coverage loss $[3,31,66]$. Besides conversion of mangrove forests for fisheries, aquaculture and agriculture was related to reduced ground water levels, and soil and water pollution from the effluents, which further intensified mangrove deforestation [127]. For example, the mangrove habitat losses in Kenya during 2000-2010 are associated with soil and water pollution [128], caused by the potential agricultural and aquacultural intensification $[66,129]$. Aquaculture and agriculture were also shown to be the main driver of losses for the CR and EN mangrove species [71,72].

Globally, shrimp and other forms of aquaculture drove conversion of $38 \%$ and $14 \%$ of the mangrove forest areas, respectively, between 1990 and 2020 [42]. Several Southeast Asian countries (Myanmar, Borneo, Malaysia, and Sumatra Island) have undergone a total 10\% areal loss of mangroves between 2000 and 2012 due to aquaculture [64]. Thailand and Vietnam are the hotspots of mangrove deforestation by aquaculture that encountered mangrove forests loss at an average rate of $0.09 \mathrm{~km}^{2}$ per year between 1990 and 2020 [39]. In Thailand, $694 \mathrm{~km}^{2}$ of mangrove areas was converted into aquaculture between 1990 and 2019, followed by $1020 \mathrm{~km}^{2}$ in Vietnam and $65 \mathrm{~km}^{2}$ in Bangladesh. In India about $40 \%$ of mangrove habitats on the western coastline has been transformed for aquaculture [130]. About $2055 \mathrm{~km}^{2}$ and $2110 \mathrm{~km}^{2}$ of mangrove marshlands have been transformed into shrimp and other fish farms in the Philippines and Indonesia, respectively [131]. The major decline of mangrove forest in Latin America is also associated with large scale shrimp farms and agricultural development [132], such as mangrove losses of $216 \mathrm{~km}^{2}$ in Ecuador, and $115 \mathrm{~km}^{2}$ in Honduras [112].

Intensification of agriculture is another dominant driver of defoestation in all mangrove forests containing countries, particularly in South Asia and Latin America. For example, the Philippines and Indonesia lost major mangrove areas to agriculture [127]. The recent growth of oil palm plantations in Thailand, Malaysia, Sumatra, Colombia and Indonesia is the main driver of mangrove forests loss [38,133]. The increasing demand for palm oil Indonesia drove an areal expansion of palm plantation by 30\% in 2019 compared to the coverage in 2012 by replacing mangrove forests [134]. Mangroves in Central America have been mostly cleared for cattle grazing and industrial farming [135].

\subsection{Settlements and Urbanization}

The majority of our consolidated literature (98 studies) suggests human settlements and urbanization as an important anthropogenic driver of global mangrove deforestation $[31,39]$ (see Table 3). Urbanization related activities such as clearing for urban infrastructures and timber production have led to the destruction of significant mangrove areas in Asia and Africa during the past 20 years [38,136]. Human settlements occupy $150 \mathrm{~km}$ along the global coastal belt land that previously contained mangroves among other coastal wetland elements [32,137]. The human population density in coastal regions is around 80 person per sq $\mathrm{km} \mathrm{[138]} \mathrm{and} \mathrm{the} \mathrm{urbanization} \mathrm{in} \mathrm{coastal} \mathrm{areas} \mathrm{is} \mathrm{expanding,} \mathrm{par-}$ ticularly in low-lying developing countries [139]. For example, nearly $50 \%$ of the population in African countries and Bangladesh lives at the coastline, which affect the adjacent mangrove ecosystems [140].

The geographic ranges of effect for settlements and urbanization is predominantly Asia and Africa [141]. Particularly, the Indian Ocean coastline, which contains the mangrove with rich biodiversity and expands over several countries such as Sri Lanka, Myanmar, Bangladesh, Singapore, Indonesia and Australia, has been losing mangrove coverage during the last three decades due to urban encroachment [142]. Sub-Saharan countries 
such as Mauritania, Comoros, Djibouti and Somalia encountered rapid urban development and associated mangrove loss [143]. In Indonesia, Guinea, and Guinea-Bissau, mangrove forests are exploited for wood harvesting and timber extraction [63] [144]. The VU species Avicennia rumphiana that dominantly occurs in Southeast Asia is threatened by the expansion of human settlements [19].

\subsection{Industrialization and Pollution}

Industrialization and pollution represent an emerging group of driver for mangrove deforestation as reported by $15 \%$ of our consolidated literature (Table 3) [145]. The Caribbean mangrove zone, which encountered the second highest areal loss after Asia over the past three decades, was impacted by sewage, oil pollution, solid waste and conversion to landfills, mainly driven by rapid industrialization [7,146,147]. In India, a considerable amount of stress on mangroves is caused by domestic and industrial waste, heavy metals and other toxic discharge from thermal power stations in Ennore and Tuticorin [148], Vedanta Sterlite Copper industry in Tuticorin, nuclear power plants (Kudankulam and Kalpakkam) [149] and dye factories. Recent proposal by the Indian Government for drilling in the Cauvery delta region for hydrocarbon and methane exploration threatened Pichavaram mangrove forest, Tamilnadu, which is only 490 meters away from the exploration zone sheltering the stretch of the Tamilnadu coast from natural calamities such as the 2004 tsunami [150].

Petroleum explorations, such as in the Persian Gulf zone and resulted oil wells, oil refiners and oil transport led to pollutions from oil spills driving substantial mangrove habitat losses [151]. They can also lead to accidents, for example, the Gulf of Mexico oil spill in 2010 affected $10 \%$ areas of mangrove forests in with a residue impact lasting for 10 years [152]. On January 2017, the toxic bunker oil spill along the coast of Chennai, India spread $34 \mathrm{~km}$ across the Ennore coast and reached Pichavaram and Pulicat mangrove forests affecting several native mangrove species [153].

Immobilization of heavy metals, such as Copper, Iron, Magnesium, Manganese, Zinc, Mercury, Lead and Tin, has emerged as a driver of mangrove deforestation globally $[154,155]$. At a low level of heavy metal contamination, mangrove forests may act as biological pollution sinks [156]. Depending on the nutrients cycles and sediment characteristics, mangroves can dissolve metals in the deposits by exuding oxygen into the anoxic soil sediment through aerial roots $[32,145,157,158]$. However, the increasing contamination and discharge of heavy metals are exceeding the mangrove sink capacity and causing direct damages by pollution [155].

\subsection{Flow modification}

Flow modification by diverting upland water flows from mangroves diminishes mangrove productivity, as identified by $20(8 \%)$ of our consolidated literature [136]. In Asia, the construction of upstream reservoirs and dams reduced the supply of sediments to several deltaic mangrove regions, including Ganges and Cauvery in India, the Sundarbans deltas of India and Bangladesh and Indus river delta of Pakistan, leading to an increase in wetland erosions in these regions [159]. Likewise, the annual sediment flow to the deltaic regions of China has reduced to 0.4 billion metric tons in 1994 to 1.1 billion metric tons in 2009 [87,143].

Coastal erosion prevention structures and seawalls lead to the modification of surface run-off by increasing downwards currents and inundation in the mangrove forests during flash flood events [63,153,160]. In the Mississippi Delta, construction of flood control walls led to hydrological disturbances in the deltaic plain and an isolation of the river from the Delta affecting the mangrove zone [161,162]. Conversion of mangrove areas into salt pans and construction of river dams are the major causes of mangrove deforestation in Brazil [163]. 


\section{Interactions among drivers}

Mangrove deforestation is the outcome of the complex interactions among the interconnected environmental and anthropogenic drivers [164]. Our consolidated literature suggest that the drivers may interact within and across their groups and may thus amplify their impacts on mangroves $[120,143,165]$ (Figure 3). For example, climate change induced decreased precipitation and drought events lead to an increase in the groundwater extraction [30]. The increase in the upstream groundwater extraction in turn leads to an increased level of salinity intrusion in the downstream coastal mangrove zones [166]. Moreover, expansion of aquaculture also leads to an increase in groundwater extraction in the coastal zones, which also in turn leads to an increased salinity intrusion [40].

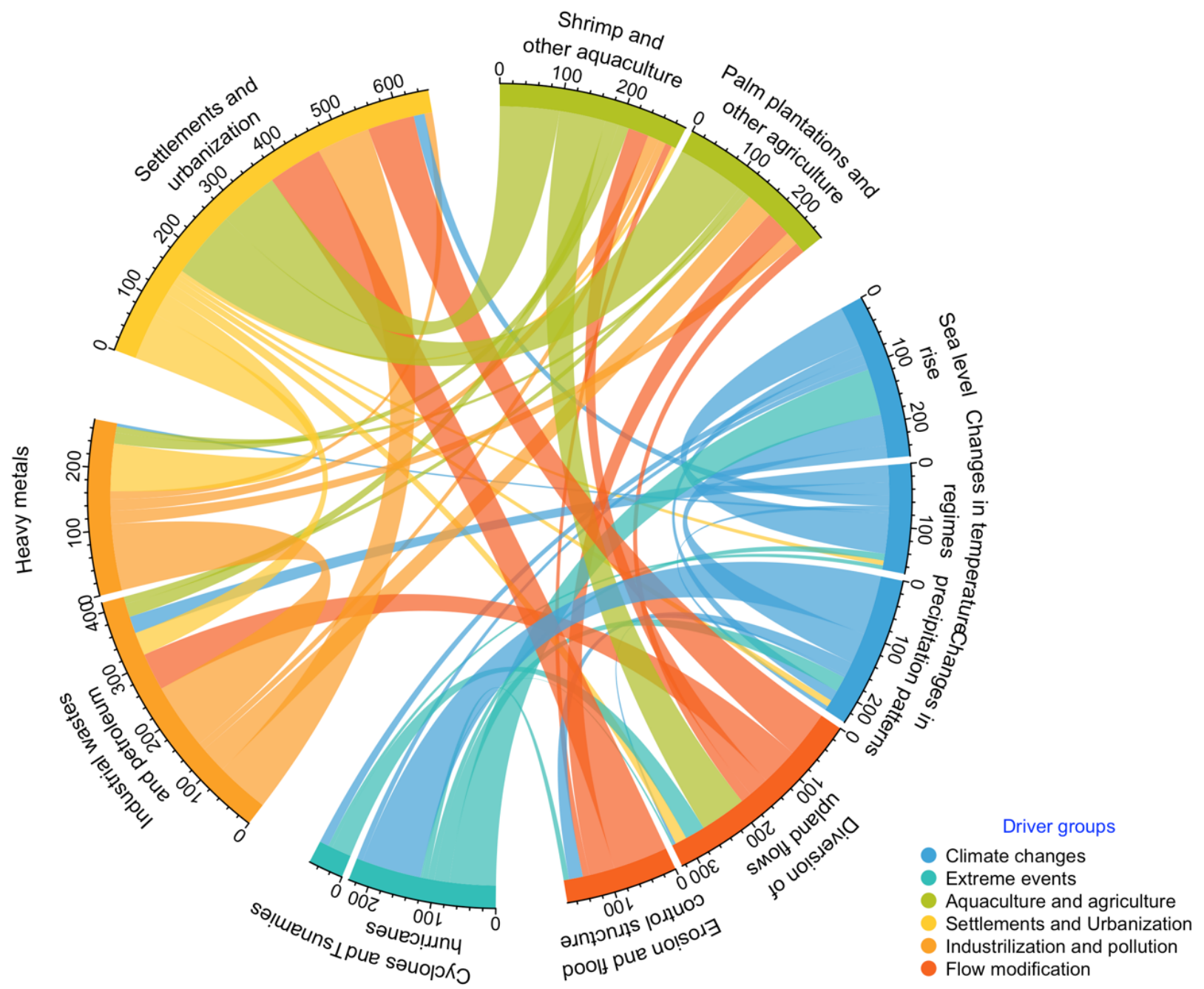

Figure 3. Interactions among the identified drivers and drivers groups of mangrove deforestation. The scale indicates the number of consolidated studies indicating such interactions.

Settlements and urbanization in the costal wetland zones directly lead to interruptions and alternations in the hydrological and sedimentation processes [167]. Settlements and urbanization are also major sources of pollution and nutrients overload [12]. The urbanization processes also lead to an expansion of aquaculture and agriculture in the vicinity, which may also be sources for pollution in the mangroves [168]. In fact, the driver groups aquaculture and agriculture and industrialization and pollution exhibited the strongest interaction in our consolidated literature (Figure 3). 
A considerable dieback of mangrove forests occurred between 2015 and 2016 in the Northwest Australian coastline is a strong manifestation of the interaction of drivers $[169,170]$. Mangrove forests on the coastline bounding low-lying plains of Australia's Gulf of Carpentaria progressively extended inland and to a lesser extent in a seaward direction between 1987 and 2015. However, between 2015 and 2016, a significant dieback occurred in several mangrove regions of the North and Northwest Australia $[169,170]$. The dieback is driven by a complex interaction among long term temperature and precipitation anomalies, El Niño Southern Oscillation (ENSO) related variation in sea level, particularly a 20$30 \mathrm{~cm}$ decline in sea level during the immediate pre-dieback period and a $20-30 \%$ increase in soil salinization above the pre-dieback level [170]. The interaction among these drivers led to mangrove canopy loss, reduced Normalized Difference Vegetation Index (NDVI) and reduced recruitment, which in combination led to an irreversible dieback event.

Global warming can amplify and widen the ranges of plant diseases and insect pests, such as fungal fruit and leaf diseases and wood-boring and leaf-feeding beetles, by spreading their habitats and creating favorable condition for reproduction $[18,171]$. These diseases and pests can lead to mangrove deforestation through branch and stem cankers, die-back and leaf galls [18]. Several mangrove species were shown to be vulnerable to these global warming led diseases and pests, such as Barringtonia racemosa is vulnerable to fruit and leaf diseases and Hibiscus tiliaceus is vulnerable to herbivory beetles [171]. The die-back and canker levels observed in A. marina are also associated with these diseases and pests.

The impacts of sea-level rise have been exacerbated by coastal subsidence in several regions [172]. Coastal subsidence results from excessive extraction of subsurface ground water and variations in the thermal expansion across geographies, which lead to the vertical motion of the landform during the tectonic movement [173]. Coastal erosion and sediment deposition from the banks of large rivers have further increased subsidence levels through silt depositions [107]. The subsidence is particularly evident along the shorelines where mangrove forests area are located [10,173]. Several deltaic regions, including Changjiang river delta (China), Chao phraya delta (Thailand) and Mississippi river delta (Gulf of Mexico), were identified as extremely sensitive to sea-level fluctuations due to subsidence [162,174,175]. Most of the mangrove forests in Ganges-Brahmaputra-Meghna delta in India and Bangladesh are affected simultaneously by subsidence due to ground water extraction and erosion from the monsoons rains, and accelerated sea-level-rise, which has led to substantial habitat loss of the Sundarbans mangroves [176].

The aftermaths of extreme events may create opportunities for several anthropogenic drivers, such as aquaculture and agriculture $[79,177,178]$. For example, the South and North provinces in Thailand have converted the tsunami damaged mangrove areas into aquaculture and agricultural lands [79]. Around $1000 \mathrm{~km}^{2}$ of the degraded mangrove forests in Asia were converted to other land forms (e.g. for agriculture and aquaculture) between 1990 and 2020, largely triggered by the development policies for hurricane damaged lands [29,35,178,179].

The drivers and their interactions may go beyond the specific drivers of mangrove deforestation. Several coastal ecosystems, such as ocean algae, coral reefs and seagrasses, are closely associated with adjacent mangrove forests [53,180]. For example, coral reefs supply nutrition to the downstream mangrove forests shaping overall mangrove health and seedling rates [181]. Drivers affecting these adjacent coastal ecosystems also passively affect mangrove forests, e.g. bleaching of coral reefs will decrease nutrition flows and in turn lower productivity of mangrove forests [53,182].

\section{Conclusions and outlook}

This review contributes with a global synthesis of the mangrove deforestation scenario over three decades, i.e. between 1990 and 2020. Our global level synthesis indicates the Southeast Asian region as particularly vulnerable to mangrove deforestation with the 
highest loss of mangrove coverage between 1990 and 2020 (Table 2). Consequently, we urge for strong mangrove monitoring and conservation measures in the Asian region, particularly in countries like Indonesia, Malaysia and Bangladesh.

Several technical difficulties have been reported by our consolidated studies regarding monitoring of mangrove regions. For example, most of the deforested mangrove areas replaced with agriculture or other plantations has been misclassified as mangrove forests, particularly in Indonesia [64]. This is due to oil palm plantations and palm orchards that replace mangrove forests may reflect the same color bands in satellite images [134]. Also, even though the mangrove forests in Brazil have been substantially affected by human settlements, aquaculture and water pollution, little mangrove area loss has been documented since 1980 [68].

Technical difficulties also remain in quantifying anthropogenic drivers' impacts, for example, quantification of the impacts of population increase and urbanization on mangrove forests coverage in Asia (Gandhi and Jones 2019a, Giri et al 2015, Latiff and Faridah-Hanum 2014). The advent of satellite imageries and sophisticated image classification and detection techniques have advanced quantification and trend analyses for anthropogenic activities [31]. Future research should focus on advancing the quantification of the association between anthropogenic drivers and mangrove coverage changes in under studied regions.

We also drew on 11 threatened mangrove species and their native geographic ranges. Many of these species may soon be locally extinct, e.g. Sonneratia griffithii and Bruguiera hainseii [71] in Asia. Local extinction of these species may infer global loss. According to IUCN, there are no conservation measures specific to most of these threatened species. We therefore recommend a continued monitoring and research on these species, as well as the inclusion of these species in the marine and coastal areas protection programs [68]. Although mangroves are protected and marginally restored during the last decades in several regions (for example, Avicennia integra [73] has been conserved in a remote area of northern Australia [184,185]), little is known about the achievements of these local conservation efforts while mangrove areas globally continued to decline. Hence, a global coordination of these in-situ conservation actions is required with a correct management of Protected Areas Network, to fully protect species and the entire mangrove ecosystems [186,187].

We identified two major groups of environmental drivers: climate changes and extreme events, and four groups of anthropogenic drivers: aquaculture and agriculture, settlements and urbanization, industrialization and pollution and flow modification, which led to the mangrove deforestation globally observed in our consolidated literature. Our reviewed studies pointed to aquaculture and agriculture and related anthropogenic activities as the predominant driver of global mangrove deforestation although the geographic ranges of their effects varied (Table 3). Gradual climate variations, i.e. seal-level rise, precipitation and temperature changes, constitute the second major group of drivers of deforestation of the global mangrove forest with visible direct impacts on the equatorial regions, e.g. Central America and Asia. Settlements and urbanization constitute the third major group of drivers and were indicated as the main drivers of mangrove deforestation in Asia and Africa including India, Bangladesh, Thailand, Vietnam, Mauritania, Comoros, Djibouti and Somalia by the majority of our consolidated literature (Table 3). However, the data for drivers available from certain areas needed to be consolidated to arrive at our global drivers database and therefore, a robust global drivers database for mangrove deforestation requires a precise global assessment, e.g. regular updates of Global Mangrove Watch [11]. Our review results can contribute to update the datasets for assisting the development of policies for mangrove conservation. Such global level assessments will also be helpful for disentangling and quantifying the associations of climatic changes and anthropogenic activities with mangrove cover changes globally and also for predicting future mangrove patterns and provision of ecosystem services. 
The complex interactions among the drivers identified in this review indicates that mitigating drivers of mangrove deforestation may have co-benefits for other ecosystems. For example, bad shrimp farming practices and produced pollution degrade mangroves but also adjacent freshwater and coastal ecosystems [188]. Investments in proper shrimp farming infrastructure and development of sewage treatment plants will thus benefit both mangrove forests and those adjacent ecosystems [42]. The consequent increase in the availability of usable freshwater may in turn decrease the pressure on groundwater extraction and thus reduce salinity intrusion to mangroves.

Overall, mangrove conservation should be prioritized over restoration. Measures have been taken to restore the wetlands by diverting the river water into the wetlands and by creating marshes by pumping the dredged sediments [32]. However, these measures are expensive and unaffordable in many places and may have adverse consequences for other ecosystems [32].

Author Contributions: A.K.B. and P.C. conceived the study. R.P. conducted the review under the supervision of A.K.B, P.C. and M.M.R. A.K.B. and R.P. wrote the article and all reviewed and revised the article. M.M.R. provided information and input regarding mangrove species.

Funding: This study was supported through the FCT (Fundação para a Ciência e a Tecnologia) under the projects PTDC/CTA-AMB/28438/2017-ASEBIO and UIDB/04152/2020-Centro de Investigação em Gestão de Informação (MagIC).

Conflicts of Interest: The authors declare no conflict of interest.

\section{References}

1. Friess, D.A.; Rogers, K.; Lovelock, C.E.; Krauss, K.W.; Hamilton, S.E.; Lee, S.Y.; Lucas, R.; Primavera, J.; Rajkaran, A.; Shi, S. The State of the World's Mangrove Forests: Past, Present, and Future. Annu. Rev. Environ. Resour. 2019, 44, 89-115, doi:10.1146/annurev-environ-101718-033302.

2. Romañach, S.S.; DeAngelis, D.L.; Koh, H.L.; Li, Y.; Teh, S.Y.; Raja Barizan, R.S.; Zhai, L. Conservation and Restoration of Mangroves: Global Status, Perspectives, and Prognosis. Ocean $\mathcal{E}$ Coastal Management 2018, 154, 72-82, doi:10.1016/j.ocecoaman.2018.01.009.

3. Worthington, T.; Spalding, M. Mangrove Restoration Potential. A Global Map Highlighting a Critical Opportunity; The Nature Conservancy, 2018; p. 36;

4. Mangrove Ecosystems: A Global Biogeographic Perspective; 2017;

5. Barbier, E.B. The Protective Service of Mangrove Ecosystems: A Review of Valuation Methods. Marine Pollution Bulletin 2016, 109, 676-681, doi:10.1016/j.marpolbul.2016.01.033.

6. Carugati, L.; Gatto, B.; Rastelli, E.; Lo Martire, M.; Coral, C.; Greco, S.; Danovaro, R. Impact of Mangrove Forests Degradation on Biodiversity and Ecosystem Functioning. Scientific Reports 2018, 8, doi:10.1038/s41598-018-31683-0.

7. Kristensen, E.; Bouillon, S.; Dittmar, T.; Marchand, C. Organic Carbon Dynamics in Mangrove Ecosystems: A Review. Mangrove Ecology - Applications in Forestry and Costal Zone Management 2008, doi:http://dx.doi.org.ezproxy.auckland.ac.nz/10.1016/j.aquabot.2007.12.005.

8. Alongi, D.M. Carbon Cycling and Storage in Mangrove Forests. Annual Review of Marine Science 2014, 6, doi:10.1146/annurevmarine-010213-135020.

9. Spalding, M. The Global Distribution and Status of Mangrove Ecosystems. International NewsLett. Coastal Management 1997, 1, 20-21.

10. Alongi, D.M. Mangrove Forests: Resilience, Protection from Tsunamis, and Responses to Global Climate Change. Estuarine Coastal and Shelf Science 2008, 78, 1-13.

11. Spalding, M.D.; Leal, M. The State of the World's Mangroves; Global Mangrove Alliance, 2021; p. 41;.

12. 1Worthington, T.A.; Andradi-Brown, D.A.; Bhargava, R.; Buelow, C.; Bunting, P.; Duncan, C.; Fatoyinbo, L.; Friess, D.A.; Goldberg, L.; Hilarides, L.; et al. Harnessing Big Data to Support the Conservation and Rehabilitation of Mangrove Forests Globally. One Earth 2020, 2.

13. 1Bunting, P.; Rosenqvist, A.; Lucas, R.; Rebelo, L.-M.; Hilarides, L.; Thomas, N.; Hardy, A.; Itoh, T.; Shimada, M.; Finlayson, C. The Global Mangrove Watch-A New 2010 Global Baseline of Mangrove Extent. Remote Sensing 2018, 10, 1669, doi:10.3390/rs10101669. 
14. Feller, I.C.; Friess, D.A.; Krauss, K.W.; Lewis, R.R. The State of the World's Mangroves in the 21st Century under Climate Change. Hydrobiologia 2017, 803.

15. Primavera, J.H.; Esteban, J.M.A. A Review of Mangrove Rehabilitation in the Philippines: Successes, Failures and Future Prospects. Wetlands Ecology and Management 2008, 16.

16. Cormier-Salem, M.C.; Bernatets, C.; Sarr, O. Mangrove System Sustainability: Public Incentives and Local Strategies in West Africa. In Tropical Deltas and Coastal Zones: Food Production, Communities and Environment at the Land-Water Interface; 2010.

17. Asbridge, E.; Lucas, R.; Accad, A.; Dowling, R. Mangrove Response to Environmental Changes Predicted under Varying Climates: Case Studies from Australia. Current Forestry Reports 2015, 1, doi:10.1007/s40725-015-0018-4.

18. Giesen, W.; Wulffraat, S.; Zieren, M.; Scholten, L. Mangrove Guidebook for Southeast Asia; 2007;

19. Mangaoang, C.; Flores, A. Inventory of Mangroves in Katunggan Coastal Eco-Park, Sultan Kudarat Province, the Philippines. Bonorowo Wetlands 2019, 9, doi:10.13057/bonorowo/w90202.

20. Ragavan, P.; Saxena, M.; Saxena, A.; Mohan, P.M.; Sachithanandam, V.; Coomar, T. Floral Composition and Taxonomy of Mangroves of Andaman and Nicobar Islands. Indian Journal of Geo-Marine Sciences 2014, 43.

21. Sheue, C.R.; Liu, H.Y.; Yong, J.W.H. Kandelia Obovata (Rhizophoraceae), a New Mangrove Species from Eastern Asia. Taxon 2003, 52, 287-294, doi:10.2307/3647398.

22. Dahdouh-Guebas, F.; Van Pottelbergh, I.; Kairo, J.G.; Cannicci, S.; Koedam, N. Human-Impacted Mangroves in Gazi (Kenya): Predicting Future Vegetation Based on Retrospective Remote Sensing, Social Surveys, and Tree Distribution. Marine Ecology Progress Series 2004, 272, 77-92, doi:10.3354/meps272077.

23. Fromard, F.; Vega, C.; Proisy, C. Half a Century of Dynamic Coastal Change Affecting Mangrove Shorelines of French Guiana. A Case Study Based on Remote Sensing Data Analyses and Field Surveys. Marine Geology 2004, 208, 265-280, doi:10.1016/j.margeo.2004.04.018.

24. López-Angarita, J.; Roberts, C.M.; Tilley, A.; Hawkins, J.P.; Cooke, R.G. Mangroves and People: Lessons from a History of Use and Abuse in Four Latin American Countries. Forest Ecology and Management 2016, 368, 151-162.

25. Djamaluddin, R.; Brown, B.; Lewis, R.R. The Practice of Hydrological Restoration to Rehabilitate Abandoned Shrimp Ponds in Bunaken National Park, North Sulawesi, Indonesia. Biodiversitas 2019, 20, 160-170, doi:10.13057/biodiv/d200119.

26. Bhowmik, A.K.; Cabral, P. Cyclone Sidr Impacts on the Sundarbans Floristic Diversity. Earth Science Research 2013, 2, 62-79, doi:10.5539/esr.v2n2p62.

27. Williams, N. Tsunami Insight to Mangrove Value. Current Biology 2005, 15, R73, doi:10.1016/j.cub.2005.01.015.

28. Primavera, J.H. Development and Conservation of Philippine Mangroves: Institutional Issues. Ecological Economics 2000, 35, 91106, doi:10.1016/S0921-8009(00)00170-1.

29. Maung, W.S.; Sasaki, J. Assessing the Natural Recovery of Mangroves after Human Disturbance Using Neural Network Classification and Sentinel-2 Imagery in Wunbaik Mangrove Forest, Myanmar. Remote Sensing 2021, 13, doi:10.3390/rs13010052.

30. Islam, S.; Gnauck, A. Water Shortage in the Gorai River Basin and Damage of Mangrove Wetland Ecosystems in Sundarbans, Bangladesh. 3rd International Conference on Water E Flood Management (ICWFM-2011) 2011.

31. Goldberg, L.; Lagomasino, D.; Thomas, N.; Fatoyinbo, T. Global Declines in Human-driven Mangrove Loss. Glob. Change Biol. 2020, 26, 5844-5855, doi:10.1111/gcb.15275.

32. Tam, N.F.Y. Pollution Studies on Mangroves in Hong Kong and Mainland China. In The Environment in Asia Pacific Harbours; 2006 ISBN 140203654X.

33. Baldwin, A.; Egnotovich, M.; Ford, M.; Platt, W. Regeneration in Fringe Mangrove Forests Damaged by Hurricane Andrew. Plant Ecology 2001, 157, doi:10.1023/A:1013941304875.

34. Godoy, M.D.P.; De Lacerda, L.D. Mangroves Response to Climate Change: A Review of Recent Findings on Mangrove Extension and Distribution. Anais da Academia Brasileira de Ciencias 2015, 87, doi:10.1590/0001-3765201520150055.

35. Krauss, K.W.; Osland, M.J. Tropical Cyclones and the Organization of Mangrove Forests: A Review. Annals of Botany $2020,125$.

36. Charrua, A.B.; Padmanaban, R.; Cabral, P.; Bandeira, S.; Romeiras, M.M. Impacts of the Tropical Cyclone Idai in Mozambique: A Multi-Temporal Landsat Satellite Imagery Analysis. Remote Sensing 2021, 13, 201.

37. Das, S. Can Mangroves Minimize Property Loss during Big Storms?: An Analysis of House Damages Due to the Super Cyclone in Orissa; 2009; ISBN 9780511843938; 9781107007147.

38. Richards, D.R.; Friess, D.A. Rates and Drivers of Mangrove Deforestation in Southeast Asia, 2000-2012. Proceedings of the National Academy of Sciences of the United States of America 2016, 113, 344-349, doi:10.1073/pnas.1510272113.

39. Gandhi, S.; Jones, T.G. Identifying Mangrove Deforestation Hotspots in South Asia, Southeast Asia and Asia-Pacific. Remote Sensing 2019, 11, doi:10.3390/RS11060728.

40. Charrua, A.B.; Bandeira, S.O.; Catarino, S.; Cabral, P.; Romeiras, M.M. Assessment of the Vulnerability of Coastal Mangrove Ecosystems in Mozambique. Ocean and Coastal Management 2020, 189, 105145, doi:10.1016/j.ocecoaman.2020.105145.

41. Neumann, B.; Vafeidis, A.T.; Zimmermann, J.; Nicholls, R.J. Future Coastal Population Growth and Exposure to Sea-Level Rise and Coastal Flooding--a Global Assessment. PloS one 2015, 10, e0118571, doi:10.1371/journal.pone.0118571.

42. Jayanthi, M.; Thirumurthy, S.; Muralidhar, M.; Ravichandran, P. Impact of Shrimp Aquaculture Development on Important Ecosystems in India. Global Environmental Change 2018, 52, 10-21, doi:10.1016/j.gloenvcha.2018.05.005.

43. Sherrod, C.L.; McMillan, C. Black Mangrove, Avicennia Germinans, in Texas: Past and Present Distribution. Contributions in Marine Science 1981, 24. 
44. Fakhruddin, B.; Mahalingam, R.; Padmanaban, R. Sustainable Development Goals for Reducing the Impact of Sea Level Rise on Mangrove Forests. Indian Journal of Geo-Marine Sciences 2018, 47, 1947-1958.

45. Madhu, N. V.; Maheswaran, P.A.; Jyothibabu, R.; Sunil, V.; Revichandran, C.; Balasubramanian, T.; Gopalakrishnan, T.C.; Nair, K.K.C. Enhanced Biological Production off Chennai Triggered by October 1999 Super Cyclone (Orissa). Current Science 2002, 82, 1472-1479.

46. Das, S.; Crépin, A.-S. Mangroves Can Provide Protection against Wind Damage during Storms. Estuarine, Coastal and Shelf Science 2013, 134, 98-107, doi:10.1016/j.ecss.2013.09.021.

47. Valiela, I.; Bowen, J.L.; Yotk, J.K. Mangrove Forests: One of the World's Threatened Major Tropical Environments. BioScience 2001, 51, 807, doi:10.1641/0006-3568(2001)051[0807:mfootw]2.0.co;2.

48. Maina, J.M.; Bosire, J.O.; Kairo, J.G.; Bandeira, S.O.; Mangora, M.M.; Macamo, C.; Ralison, H.; Majambo, G.; Poulter, B. Identifying Global and Local Drivers of Change in Mangrove Cover and the Implications for Management. Global Ecol Biogeogr 2021, 30, 2057-2069, doi:10.1111/geb.13368.

49. Thomas, N.; Lucas, R.; Bunting, P.; Hardy, A.; Rosenqvist, A.; Simard, M. Distribution and Drivers of Global Mangrove Forest Change, 1996-2010. PLoS ONE 2017, 12, doi:10.1371/journal.pone.0179302.

50. Agencies, C.M. Coordinating Working Party on Fishery Statistics (CWP).

51. Hamilton, S.E.; Casey, D. Creation of a High Spatio-Temporal Resolution Global Database of Continuous Mangrove Forest Cover for the 21st Century (CGMFC-21). Global Ecology and Biogeography 2016, 25, 729-738, doi:10.1111/geb.12449.

52. Ward, R.D.; Friess, D.A.; Day, R.H.; Mackenzie, R.A. Impacts of Climate Change on Mangrove Ecosystems: A Region by Region Overview. Ecosystem Health and Sustainability 2016, 2, doi:10.1002/ehs2.1211.

53. Kodikara, K.A.S.; Jayatissa, L.P.; Huxham, M.; Dahdouh-Guebas, F.; Koedam, N. The Effects of Salinity on Growth and Survival of Mangrove Seedlings Changes with Age. Acta Botanica Brasilica 2018, 32, doi:10.1590/0102-33062017abb0100.

54. Bjorkman, O.; Demmig, B.; Andrews, T.J. Mangrove Photosynthesis: Response to High-Irradiance Stress. Australian Journal of Plant Physiology 1988, 15, doi:10.1071/pp9880043.

55. Hamilton, S.E. Botany of Mangroves. In Coastal Research Library; 2020; Vol. 33, pp. 1-40.

56. Mitsch, W.J.; Wu, X.; Nairn, R.W.; Weihe, P.E.; Wang, N.; Deal, R.; Boucher, C.E. Creating and Restoring Wetlands. BioScience 1998, 48.

57. Giri, C.; Ochieng, E.; Tieszen, L.L.; Zhu, Z.; Singh, A.; Loveland, T.; Masek, J.; Duke, N. Status and Distribution of Mangrove Forests of the World Using Earth Observation Satellite Data. Global Ecology and Biogeography 2011, 20, 154-159, doi:10.1111/j.14668238.2010.00584.x.

58. Asante, W.A.; Acheampong, E.; Boateng, K.; Adda, J. The Implications of Land Tenure and Ownership Regimes on Sustainable Mangrove Management and Conservation in Two Ramsar Sites in Ghana. Forest Policy and Economics 2017, 85, doi:10.1016/j.forpol.2017.08.018.

59. Bunting, P.; Rosenqvist, A.; Lucas, R.M.; Rebelo, L.M.; Hilarides, L.; Thomas, N.; Hardy, A.; Itoh, T.; Shimada, M.; Finlayson, C.M. The Global Mangrove Watch - A New 2010 Global Baseline of Mangrove Extent. Remote Sensing 2018, 10, doi:10.3390/rs10101669.

60. FAO Global Forest Resources Assessments.

61. Alliance Mangrove, G. FAO Reviews 30 Years of Global Forest Data.

62. Luther, D.A.; Greenberg, R. Mangroves: A Global Perspective on the Evolution and Conservation of Their Terrestrial Vertebrates. BioScience 2009, 59, 602-612, doi:10.1525/bio.2009.59.7.11.

63. Giri, Chandra, J. Lomg, S. Abbas, R. Mani Murali, F.M.Q. and D.T. Distribution and Dynamics of Mangrove Forests of South Asia. Journal of environmental management 2015, 48, 101-111.

64. Richards, D.R.; Friess, D.A. Rates and Drivers of Mangrove Deforestation in Southeast Asia, 2000-2012. Proceedings of the National Academy of Sciences 2016, 113, 344-349, doi:10.1073/pnas.1510272113.

65. Ximenes, A.C.; Ponsoni, L.; Lira, C.F.; Koedam, N.; Dahdouh-Guebas, F. Does Sea Surface Temperature Contribute to Determining Range Limits and Expansion of Mangroves in Eastern South America (Brazil)? Remote Sensing 2018, 10, doi:10.3390/rs10111787.

66. Latiff, A. a; Faridah-Hanum, I. b Mangrove Ecosystem of Malaysia: Status, Challenges and Management Strategies. In Mangrove Ecosystems of Asia; 2014; pp. 1-22 ISBN 978-1-4614-8581-0.

67. Hutchison, J.; Manica, A.; Swetnam, R.; Balmford, A.; Spalding, M. Predicting Global Patterns in Mangrove Forest Biomass. Conservation Letters 2014, 7, 233-240, doi:10.1111/conl.12060.

68. Polidoro, B.A.; Carpenter, K.E.; Collins, L.; Duke, N.C.; Ellison, A.M.; Ellison, J.C.; Farnsworth, E.J.; Fernando, E.S.; Kathiresan, K.; Koedam, N.E.; et al. The Loss of Species: Mangrove Extinction Risk and Geographic Areas of Global Concern. PLoS ONE 2010, 5, doi:10.1371/journal.pone.0010095.

69. Long, J.; Napton, D.; Giri, C.; Graesser, J. A Mapping and Monitoring Assessment of the Philippines' Mangrove Forests from 1990 to 2010. Journal of Coastal Research 2014, 294, 260-271, doi:10.2112/JCOASTRES-D-13-00057.1.

70. Duke, N., Kathiresan, K., Salmo III, S.G., Fernando, E.S., Peras, J.R., Sukardjo, S., Miyagi, T., Ellison, J.; Koedam, N.E., Wang, Y., Primavera, J., Jin Eong, O., Wan-Hong Yong, J. \& Ngoc Nam, V. Camptostemon Philippinense. The IUCN Red List of Threatened Species. 
71. Duke, N., Kathiresan, K., Salmo III, S.G., Fernando, E.S., Peras, J.R., Sukardjo, S. \& Miyagi, T. Sonneratia Griffithii. The IUCN Red List of Threatened Species.

72. Duke, N., Kathiresan, K., Salmo III, S.G., Fernando, E.S., Peras, J.R., Sukardjo, S., Miyagi, T., Ellison, J.; Koedam, N.E., Wang, Y., Primavera, J., Jin Eong, O., Wan-Hong Yong, J. \& Ngoc Nam, V. 2010b Bruguiera Hainesii. The IUCN Red List of Threatened Species.

73. Huang, X.; Zhang, L.; Wang, L. Evaluation of Morphological Texture Features for Mangrove Forest Mapping and Species Discrimination Using Multispectral IKONOS Imagery. IEEE Geoscience and Remote Sensing Letters 2009, 6, 393-397, doi:10.1109/LGRS.2009.2014398.

74. Pin, T.G.; Supriatna, J.; Takarina, N.D.; Tambunan, R.P. Mangrove Diversity and Suitability Assessments for Ecotourism in Cimalaya Wetan Coast, Karawang District, Indonesia. Biodiversitas 2021, 22, doi:10.13057/biodiv/d220234.

75. Day, J.W.; Conner, W.H.; Ley-Lou, F.; Day, R.H.; Navarro, A.M. The Productivity and Composition of Mangrove Forests, Laguna de Términos, Mexico. Aquatic Botany 1987, 27, doi:10.1016/0304-3770(87)90046-5.

76. Rowley, I.; Kirwan, G.M. Philippine Cockatoo (Cacatua Haematuropygia). In Birds of the World; 2020.

77. Liu, I.A. Conservation Genetics and Genetic Mating System of the Yellow-Shouldered Blackbird (Agelaius Xanthomus), an Endangered Island Endemic. Conservation Genetics 2015, 16, doi:10.1007/s10592-015-0721-5.

78. Field, C.D. Impact of Expected Climate Change on Mangroves. Hydrobiologia 1995, doi:10.1007/BF00029113.

79. Cochard, R.; Ranamukhaarachchi, S.L.; Shivakoti, G.P.; Shipin, O. V.; Edwards, P.J.; Seeland, K.T. The 2004 Tsunami in Aceh and Southern Thailand: A Review on Coastal Ecosystems, Wave Hazards and Vulnerability. Perspectives in Plant Ecology, Evolution and Systematics 2008, 10, 3-40, doi:10.1016/j.ppees.2007.11.001.

80. Woodroffe, C.D. The Impact of Sea-Level Rise on Mangrove Shorelines. Progress in Physical Geography 1990, 14, doi:10.1177/030913339001400404.

81. Saintilan, N.; Khan, N.S.; Ashe, E.; Kelleway, J.J.; Rogers, K.; Woodroffe, C.D.; Horton, B.P. Thresholds of Mangrove Survival under Rapid Sea Level Rise. Science 2020, 368, doi:10.1126/science.aba2656.

82. Andriyono, S.; Masithah, E.D.; Pramono, H.; Suciyono, S. First Record of The Burrowing Goby Trypuchen Vagina from Pangpang Bay, Indonesia. ILMU KELAUTAN: Indonesian Journal of Marine Sciences 2019, 24, doi:10.14710/ik.ijms.24.3.127-131.

83. Mantri, V.A.; Mishra, A.K. On Monitoring Mangrove Vegetation of Sagar Island by Remote Sensing. National Academy Science Letters-India 2006, 29, 45-48.

84. Hoque, A.K.F.; Datta, D.K. The Mangroves of Bangladesh. International Journal of Ecology and Environmental Sciences 2005.

85. Feng, Z.; Tan, G.; Xia, J.; Shu, C.; Chen, P.; Wu, M.; Wu, X. Dynamics of Mangrove Forests in Shenzhen Bay in Response to Natural and Anthropogenic Factors from 1988 to 2017. Journal of Hydrology 2020, 591, doi:10.1016/j.jhydrol.2020.125271.

86. Albert, S.; Saunders, M.I.; Roelfsema, C.M.; Leon, J.X.; Johnstone, E.; Mackenzie, J.R.; Hoegh-Guldberg, O.; Grinham, A.R.; Phinn, S.R.; Duke, N.C.; et al. Winners and Losers as Mangrove, Coral and Seagrass Ecosystems Respond to Sea-Level Rise in Solomon Islands. Environmental Research Letters 2017, 12, doi:10.1088/1748-9326/aa7e68.

87. Li, S.; Meng, X.; Ge, Z.; Zhang, L. Evaluation of the Threat from Sea-Level Rise to the Mangrove Ecosystems in Tieshangang Bay, Southern China. Ocean and Coastal Management 2015, 109, doi:10.1016/j.ocecoaman.2015.02.006.

88. Blasco, F.; Saenger, P.; Janodet, E. Mangroves as Indicator of Coastal Change. Catena 1996, 27, 167-178, doi:10.1016/03418162(96)00013-6.

89. Ellison, J.C.; Stoddart, D.R. Mangrove Ecosystem Collapse during Predicted Sea-Level Rise: Holocene Analogues and Implications. Journal of Coastal Research 1991, 7.

90. Bourne, J. Louisiana's Vanishing Wetlands: Going, Going. Science 2000, 289.

91. Cahoon, D.R. A Review of Major Storm Impacts on Coastal Wetland Elevations. Estuaries and Coasts $2006,29$.

92. Schultz, K. a. El Niño/Southern Oscillation and the Seasonal Predictability of Tropical Cyclones. In El Nino and the Southern Oscillation; 2001; Vol. 76, pp. 149-182 ISBN 9780511573125.

93. Chen, S.; Wu, R.; Chen, W. The Changing Relationship between Interannual Variations of the North Atlantic Oscillation and Northern Tropical Atlantic SST. Journal of Climate 2015, 28, doi:10.1175/JCLI-D-14-00422.1.

94. Jevrejeva, S.; Jackson, L.P.; Riva, R.E.M.; Grinsted, A.; Moore, J.C. Coastal Sea Level Rise with Warming above $2{ }^{\circ}$ C. Proceedings of the National Academy of Sciences of the United States of America 2016, 113, doi:10.1073/pnas.1605312113.

95. Trenberth, K.E. Observations: Surface and Atmospheric Climate Change. Changes 2007, 164, doi:10.5194/cp-6-379-2010.

96. Meehl, G.A.; Stocker, T.F. Chapter 10. Global Climate Projections. Climate Change 2007: The Physical Science Basis 2007.

97. Hu, T.; Zhang, Y.Y.; Su, Y.; Zheng, Y.; Lin, G.; Guo, Q. Mapping the Global Mangrove Forest Aboveground Biomass Using Multisource Remote Sensing Data. Remote Sensing 2020, 12, doi:10.3390/rs12101690.

98. Liu, M.; Zhang, H.; Lin, G.; Lin, H.; Tang, D. Zonation and Directional Dynamics of Mangrove Forests Derived from TimeSeries Satellite Imagery in Mai Po, Hong Kong. Sustainability (Switzerland) 2018, 10, doi:10.3390/su10061913.

99. Cavanaugh, K.C.; Parker, J.D.; Cook-Patton, S.C.; Feller, I.C.; Williams, A.P.; Kellner, J.R. Integrating Physiological Threshold Experiments with Climate Modeling to Project Mangrove Species' Range Expansion. Glob Change Biol 2015, 21, 1928-1938, doi:10.1111/gcb.12843.

100. Stevens, P.W.; Fox, S.L.; Montague, C.L. The Interplay between Mangroves and Saltmarshes at the Transition between Temperate and Subtropical Climate in Florida. Wetlands Ecol Manage 2006, 14, 435-444, doi:10.1007/s11273-006-0006-3. 
101. Cavanaugh, K.C.; Dangremond, E.M.; Doughty, C.L.; Williams, A.P.; Parker, J.D.; Hayes, M.A.; Rodriguez, W.; Feller, I.C. Climate-Driven Regime Shifts in a Mangrove-Salt Marsh Ecotone over the Past 250 Years. Proc Natl Acad Sci USA 2019, 116, 2160221608, doi:10.1073/pnas.1902181116.

102. McCarthy, M.P.; Best, M.J.; Betts, R.A. Climate Change in Cities Due to Global Warming and Urban Effects. Geophysical Research Letters 2010, 37, doi:10.1029/2010GL042845.

103. Hoegh - Guldberg O; D, J.; M, T.; M, B.; S, B.; I, C.; A, D.; R, D.; Ebi, K.; Engelbrecht, F.; et al. Chapter 3: Impacts of 1.5C Global Warming on Natural and Human Systems. In Global Warming of $1.5^{\circ} \mathrm{C}$ an IPCC special report on the impacts of global warming of $1.5{ }^{\circ} \mathrm{C}$ above pre-industrial levels and related global greenhouse gas emission pathways, in the context of strengthening the global response to the threat of climate change; 2018.

104. Chen, Y.; Ye, Y. Effects of Salinity and Nutrient Addition on Mangrove Excoecaria Agallocha. PLoS ONE 2014, 9, doi:10.1371/journal.pone.0093337.

105. Bunt, J.S.; Williams, W.T.; Clay, H.J. River Water Salinity and the Distribution of Mangrove Species along Several Rivers in North Queensland. Australian Journal of Botany 1982, 30, doi:10.1071/BT9820401.

106. Manna, S.; Chaudhuri, K.; Bhattacharyya, S.; Bhattacharyya, M. Dynamics of Sundarban Estuarine Ecosystem: Eutrophication Induced Threat to Mangroves. Saline systems 2010, doi:10.1186/1746-1448-6-8.

107. Krauss, K.W.; Lovelock, C.E.; McKee, K.L.; López-Hoffman, L.; Ewe, S.M.L.; Sousa, W.P. Environmental Drivers in Mangrove Establishment and Early Development: A Review. Aquatic Botany 2008.

108. Fickert, T. Better Resilient than Resistant-Regeneration Dynamics of Storm-Disturbed Mangrove Forests on the Bay Island of Guanaja (Honduras) during the First Two Decades after Hurricane Mitch (October 1998). Diversity 2018, 10, doi:10.3390/d10010008.

109. IPCC Climate Change 2007. The Physical Science Basis; 2007;

110. Granek, E.F.; Ruttenberg, B.I. Protective Capacity of Mangroves during Tropical Storms: A Case Study from "Wilma" and "Gamma" in Belize. Marine Ecology Progress Series 2007, doi:10.3354/meps07141.

111. Rivera-Monroy, V.H.; Danielson, T.M.; Castañeda-Moya, E.; Marx, B.D.; Travieso, R.; Zhao, X.; Gaiser, E.E.; Farfan, L.M. LongTerm Demography and Stem Productivity of Everglades Mangrove Forests (Florida, USA): Resistance to Hurricane Disturbance. Forest Ecology and Management 2019, 440, doi:10.1016/j.foreco.2019.02.036.

112. Cahoon, D.R.; Hensel, P.; Rybczyk, J.; McKee, K.L.; Proffitt, C.E.; Perez, B.C. Mass Tree Mortality Leads to Mangrove Peat Collapse at Bay Islands, Honduras after Hurricane Mitch. Journal of Ecology 2003, 91, 1093-1105, doi:10.1046/j.13652745.2003.00841.x.

113. Roth, L.C. Hurricanes and Mangrove Regeneration: Effects of Hurricane Joan, October 1988, on the Vegetation of Isla Del Venado, Bluefields, Nicaragua. Biotropica 1992, 24, 375, doi:10.2307/2388607.

114. Ahmed, A.; Aziz, A.; Khan, A.N.A.; Islam, M.N.; Iqubal, K.F.; Nazma; Islam, M.S. Tree Diversity as Affected by Salinity in the Sundarban Mangrove Forests, Bangladesh. Bangladesh Journal of Botany 2011, 40, doi:10.3329/bjb.v40i2.9778.

115. Das, S.; Vincent, J.R. Mangroves Protected Villages and Reduced Death Toll during Indian Super Cyclone. Proceedings of the National Academy of Sciences of the United States of America 2009, 106, doi:10.1073/pnas.0810440106.

116. Ayyappan, K.; Thiruvenkatasamy, K.; Arumugam, T. Impact Assessment Study of Cyclone Vardah on Chennai, On East Coast of Tamil Nadu, India. TIDEE (TERI Information Digest on Energy E Environment) 2017, 16.

117. Muthusamy, S.; Sivakumar, K.; Durai, A.; Sheriff, M. Ockhi Cyclone and Its Impact in the Kanyakumari District of Southern Tamilnadu, India: An Aftermath Analysis. International Journal of Recent Research Aspects 2018, 1, 466-469.

118. Nivedita Priyadarshini, K.; Sivashankari, V.; Shekhar, S. An Assessment of Land Cover Change Dynamics of Gaja Cyclone in Coastal Tamil Nadu, India Using Sentinel 1 SAR Dataset. In Proceedings of the International Archives of the Photogrammetry, Remote Sensing and Spatial Information Sciences - ISPRS Archives; 2019; Vol. 42.

119. Meyers, R.A. Extreme Environmental Events; 2011; ISBN 978-1-4419-7694-9.

120. Danielsen, F.; Sørensen, M.K.; Olwig, M.F.; Selvam, V.; Parish, F.; Burgess, N.D.; Hiraishi, T.; Karunagaran, V.M.; Rasmussen, M.S.; Hansen, L.B.; et al. The Asian Tsunami: A Protective Role for Coastal Vegetation. Science 2005, 310, 643, doi:10.1126/science.1118387.

121. FAO FAO Fisheries and Aquaculture Department,Mangrove Forest Management Guidelines. FAO Forestry Paper, FAO Fisheries and Aquaculture Department, Rome 2004.

122. Kusmana, C. Distribution and Current Status of Mangrove Forests in Indonesia. In Mangrove Ecosystems of Asia: Status, Challenges and Management Strategies; 2014; pp. 37-60 ISBN 9781461485827.

123. Prasad, P.R.C.; Reddy, C.S.; Rajan, K.S.; Raza, S.H.; Dutt, C.B.S. Assessment of Tsunami and Anthropogenic Impacts on the Forest of the North Andaman Islands, India. International Journal of Remote Sensing 2009, doi:10.1080/01431160802460070.

124. Barbier, E.B. Natural Barriers to Natural Disasters: Replanting Mangroves after the Tsunami. Frontiers in Ecology and the Environment 2006, 4, 124-131, doi:10.1890/1540-9295(2006)004[0124:NBTNDR]2.0.CO;2.

125. Dharanirajan, K.; Kasinatha Pandian, P.; Gurugnanam, B.; Narayanan, R.M.; Ramachandran, S. An Integrated Study for the Assessment of Tsunami Impacts: A Case Study of South Andaman Island, India Using Remote Sensing and GIS. Coastal Engineering Journal 2007, 49, doi:10.1142/S0578563407001617.

126. Tappin, D.R.; Watts, P.; Grilli, S.T. The Papua New Guinea Tsunami of 17 July 1998: Anatomy of a Catastrophic Event. Natural Hazards and Earth System Sciences 2008, 8, doi:10.5194/nhess-8-243-2008. 
127. Primavera, J.H. Socio-Economic Impacts of Shrimp Culture. Aquaculture Research 1997, doi:10.1111/j.1365-2109.1997.tb01006.x.

128. Bosire, J.O.; Kaino, J.J.; Olagoke, A.O.; Mwihaki, L.M.; Ogendi, G.M.; Kairo, J.G.; Berger, U.; Macharia, D. Mangroves in Peril: Unprecedented Degradation Rates of Peri-Urban Mangroves in Kenya. Biogeosciences 2014, 11, doi:10.5194/bg-11-2623-2014.

129. Murdiyarso, D.; Purbopuspito, J.; Kauffman, J.B.; Warren, M.W.; Sasmito, S.D.; Donato, D.C.; Manuri, S.; Krisnawati, H.; Taberima, S.; Kurnianto, S. The Potential of Indonesian Mangrove Forests for Global Climate Change Mitigation. Nature Climate Change 2015, 5, 1089-1092, doi:10.1038/nclimate2734.

130. Quimby, B. Emerging Customs: Small-Scale Fishing Practices in Aceh, Indonesia. Applied Geography 2015, 59, doi:10.1016/j.apgeog.2014.11.026.

131. Ahmed, N.; Thompson, S.; Glaser, M. Integrated Mangrove-Shrimp Cultivation: Potential for Blue Carbon Sequestration. Ambio 2018, 47, doi:10.1007/s13280-017-0946-2.

132. Lacerda, L.D. Conservation and Sustainable Utilization of Mangrove Forests in Latin America and Africa Regions. America 1992, 114190, 44.

133. Kadarsah, A.; Salim, D.; Husain, S.; Dinata, M. Species Density and Lead (Pb) Pollution in Mangrove Ecosystem, South Kalimantan. Jurnal Biodjati 2020, 5, doi:10.15575/biodjati.v5i1.7411.

134. Euler, M.; Schwarze, S.; Siregar, H.; Qaim, M. Oil Palm Expansion among Smallholder Farmers in Sumatra, Indonesia. Journal of Agricultural Economics 2016, 67, doi:10.1111/1477-9552.12163.

135. Son, N.T.; Chen, C.F.; Chen, C.R. Mapping Mangrove Density from Rapideye Data in Central America. Open Geosciences 2017, 9, doi:10.1515/geo-2017-0018.

136. Alongi, D.M.D.M. Present State and Future of the World's Mangrove Forests. Environmental Conservation 2002, 29, 331-349, doi:10.1017/S0376892902000231.

137. Small, C.; Gornitz, V.; Cohen, J.E. Coastal Hazards and the Global Distribution of Human Population. Environmental Geosciences 2000, 7, doi:10.1046/j.1526-0984.2000.71005.x.

138. United Nations World Urbanization Prospects - Population Division. United Nations 2019.

139. Padmanaban, R.; Bhowmik, A.K.; Cabral, P.; Zamyatin, A.; Almegdadi, O.; Shuangao, W. Modelling Urban Sprawl Using Remotely Sensed Data: A Case Study of Chennai City, Tamilnadu. Entropy 2017, 19, 163, doi:10.3390/e19040163.

140. Simard, M.; Grandi, G.D.E.; Saatchi, S.; Mayaux, P. Mapping Tropical Coastal Vegetation Using JERS-1 and ERS-1 Radar Data with a Decision Tree Classifier. International Journal of Remote Sensing 2002, 23, 1461-1474, doi:10.1080/01431160110092984.

141. Whitehead, P.G.; Barbour, E.; Futter, M.N.; Sarkar, S.; Rodda, H.; Caesar, J.; Butterfield, D.; Jin, L.; Sinha, R.; Nicholls, R.; et al. Impacts of Climate Change and Socio-Economic Scenarios on Flow and Water Quality of the Ganges, Brahmaputra and Meghna (GBM) River Systems: Low Flow and Flood Statistics. Environ. Sci.: Processes Impacts 2015, 17, 1057-1069, doi:10.1039/C4EM00619D.

142. Kathiresan, K.; Rajendran, N. Mangrove Ecosystems of the Indian Ocean Region. Indian Journal of Marine Sciences $2005,34$.

143. Myers, S.S. Global Environmental Change: The Threat to Human Health. Worldwatch Paper 2009.

144. Farley, J.; Batker, D.; De La Torre, I.; Hudspeth, T. Conserving Mangrove Ecosystems in the Philippines: Transcending Disciplinary and Institutional Borders. Environmental Management 2010, 45, doi:10.1007/s00267-009-9379-4.

145. Zhang, Z.W.; Xu, X.R.; Sun, Y.X.; Yu, S.; Chen, Y.S.; Peng, J.X. Heavy Metal and Organic Contaminants in Mangrove Ecosystems of China: A Review. Environmental Science and Pollution Research 2014, 21, doi:10.1007/s11356-014-3100-8.

146. Barbosa, F.M.A.; Cuambe, C.C.; Bandeira, S.O. Status and Distribution of Mangroves in Mozambique. South African Journal of Botany 2001, 67, 393-398, doi:10.1016/S0254-6299(15)31155-8.

147. Hendy, I.W.; Michie, L.; Taylor, B.W. Habitat Creation and Biodiversity Maintenance in Mangrove Forests: Teredinid Bivalves as Ecosystemengineers. PeerJ 2014, 2014, doi:10.7717/peerj.591.

148. Selvam, S.; Venkatramanan, S.; Singaraja, C. A GIS-Based Assessment of Water Quality Pollution Indices for Heavy Metal Contamination in Tuticorin Corporation, Tamilnadu, India. Arabian Journal of Geosciences 2015, 8, doi:10.1007/s12517-015-1968-3.

149. Chidambaram, S.; Karmegam, U.; Prasanna, M. V.; Sasidhar, P. A Study on Evaluation of Probable Sources of Heavy Metal Pollution in Groundwater of Kalpakkam Region, South India. Environmentalist 2012, 32, doi:10.1007/s10669-012-9398-1.

150. Hindu, T. The Hindu. Chennai 2017, p. 1.

151. Duke, N.C. Oil Spill Impacts on Mangroves: Recommendations for Operational Planning and Action Based on a Global Review. Marine Pollution Bulletin 2016, 109, doi:10.1016/j.marpolbul.2016.06.082.

152. Goldstein, B.D.; Osofsky, H.J.; Lichtveld, M.Y. The Gulf Oil Spill. The New England journal of medicine 2011, 364, 1334-1348, doi:10.1056/NEJMra1007197.

153. Han, Y.; Nambi, I.M.; Prabhakar Clement, T. Environmental Impacts of the Chennai Oil Spill Accident - A Case Study. Science of the Total Environment 2018, 626, doi:10.1016/j.scitotenv.2018.01.128.

154. Sruthi, P.; Shackira, A.M.; Puthur, J.T. Heavy Metal Detoxification Mechanisms in Halophytes: An Overview. Wetlands Ecology and Management 2017, 25.

155. Mandura, a S. A Mangrove Stand under Sewage Pollution Stress: Red Sea. Mangroves and Salt Marshes 1997, doi:10.1023/A:1009927605517.

156. Maiti, S.K.; Chowdhury, A. Effects of Anthropogenic Pollution on Mangrove Biodiversity: A Review. Journal of Environmental Protection 2013, 04, 1428-1434, doi:10.4236/jep.2013.412163. 
157. Ellison, A.M.; Farnsworth, E.J. Anthropogenic Disturbance of Caribbean Mangrove Ecosystems: Past Impacts, Present Trends, and Future Predictions. Biotropica 1996, 28, 549, doi:10.2307/2389096.

158. Hemminga, M.A.; Slim, F.J.; Kazungu, J.; Ganssen, G.M.; Nieuwenhuize, J.; Kruyt, N.M. Carbon Outwelling from a Mangrove Forest with Adjacent Seagrass Beds and Coral Reefs (Gazi Bay, Kenya). Marine Ecology Progress Series 1994, 106, doi:10.3354/meps106291.

159. Rudra, K. Rivers of the Ganga-Brahmaputra-Meghna Delta: An Overview. In; 2018.

160. Khare, D.; Patra, D.; Mondal, A.; Kundu, S. Impact of Landuse/Land Cover Change on Run-off in a Catchment of Narmada River in India. Applied Geomatics 2014, doi:10.1007/s12518-014-0148-6.

161. Day, J.W.; Conner, W.H.; Costanza, R.; Kemp, G.P.; Mendelssohn, I.A. Impacts of Sea Level Rise on Coastal Systems with Special Emphasis on the Mississippi River Deltaic Plain. In Climate and sea level change: observations, projections and implications; 1994; pp. 276-296.

162. McKee, K.L.; Vervaeke, W.C. Will Fluctuations in Salt Marsh-Mangrove Dominance Alter Vulnerability of a Subtropical Wetland to Sea-Level Rise? Global Change Biology 2018, 24, doi:10.1111/gcb.13945.

163. Ferreira, A.C.; Lacerda, L.D. Degradation and Conservation of Brazilian Mangroves, Status and Perspectives. Ocean and Coastal Management 2016, 125, doi:10.1016/j.ocecoaman.2016.03.011.

164. Adame, M.F.; Hermoso, V.; Perhans, K.; Lovelock, C.E.; Herrera-Silveira, J.A. Selecting Cost-Effective Areas for Restoration of Ecosystem Services. Conservation Biology 2015, 29, 493-502, doi:10.1111/cobi.12391.

165. Fadzil, M.F.; Yun, P.S.; Razal, A.R.; Chee, P.S.; Suratman, S.; Dagang, N.S.; Tahir, N.M. Oil and Grease and Total Petroleum Hydrocarbons in the Waters of Ramsar Gazetted Mangrove Area, Johor. Journal of Sustainability Science and Management 2017, 12.

166. Committee, A.T.; Rise, S.; Effects, I. Effects of Sea-Level Rise on Bays and Estuaries. Journal of Hydraulic Engineering 1992, doi:10.1061/(ASCE)0733-9429(1992)118:1(1).

167. 167. Lee, S.Y.; Dunn, R.J.K.; Young, R.A.; Connolly, R.M.; Dale, P.E.R.; Dehayr, R.; Lemckert, C.J.; McKinnon, S.; Powell, B.; Teasdale, P.R.; et al. Impact of Urbanization on Coastal Wetland Structure and Function. In Proceedings of the Austral Ecology; 2006; Vol. 31.

168. Rosasco, P.; Sdino, L.; Magoni, S. Reclamation Costs and Their Weight in the Economic Sustainability of a Project. Procedia Social and Behavioral Sciences 2016, doi:10.1016/j.sbspro.2016.05.351.

169. Asbridge, E.F.; Bartolo, R.; Finlayson, C.M.; Lucas, R.M.; Rogers, K.; Woodroffe, C.D. Assessing the Distribution and Drivers of Mangrove Dieback in Kakadu National Park, Northern Australia. Estuarine, Coastal and Shelf Science 2019, 228, 106353, doi:10.1016/j.ecss.2019.106353.

170. Lovelock, C.E.; Feller, I.C.; Reef, R.; Hickey, S.; Ball, M.C. Mangrove Dieback during Fluctuating Sea Levels. Sci Rep 2017, 7, 1680, doi:10.1038/s41598-017-01927-6.

171. Osorio, J.A.; Crous, C.J.; Wingfield, M.J.; de Beer, Z.W.; Roux, J. An Assessment of Mangrove Diseases and Pests in South Africa. Forestry 2017, foresj;cpw063v1, doi:10.1093/forestry/cpw063.

172. Syvitski, J.P.M.; Kettner, A.J.; Overeem, I.; Hutton, E.W.H.; Hannon, M.T.; Brakenridge, G.R.; Day, J.; Vörösmarty, C.; Saito, Y.; Giosan, L.; et al. Sinking Deltas Due to Human Activities. Nature Geoscience 2009, 2, 681-686, doi:10.1038/ngeo629.

173. Gornitz, V. Sea-level Rise: A Review of Recent Past and Near-future Trends. Earth Surface Processes and Landforms 1995, 20, doi:10.1002/esp.3290200103.

174. Shi-lun, Y.; Ji-yu, C. Coatal Salt Marshes and Mangrove Swamps in China. Chinese Journal of Oceanology and Limnology 1995, 13, doi:10.1007/BF02889465.

175. Bidorn, B.; Sok, K.; Bidorn, K.; Burnett, W.C. An Analysis of the Factors Responsible for the Shoreline Retreat of the Chao Phraya Delta (Thailand). Science of the Total Environment 2021, 769, doi:10.1016/j.scitotenv.2021.145253.

176. Hale, R.P.; Wilson, C.A.; Bomer, E.J. Seasonal Variability of Forces Controlling Sedimentation in the Sundarbans National Forest, Bangladesh. Frontiers in Earth Science 2019, 7, doi:10.3389/feart.2019.00211.

177. Kanaya, G.; Suzuki, T.; Kikuchi, E. Impacts of the 2011 Tsunami on Sediment Characteristics and Macrozoobenthic Assemblages in a Shallow Eutrophic Lagoon, Sendai Bay, Japan. PLoS ONE 2015, 10, doi:10.1371/journal.pone.0135125.

178. Sandilyan, S.; Kathiresan, K. Mangrove Conservation: A Global Perspective. Biodiversity and Conservation 2012, 21, 3523-3542, doi:10.1007/s10531-012-0388-x.

179. FAO (Food and Agriculture Organization) The State of the World's Land and Water Resources for Food and Agriculture (SOLAW) Managing Systems at Risk; 2011;

180. Smith, S. V.; Buddemeier, R.W. Global Change and Coral Reef Ecosystems. Annual Review of Ecology and Systematics 1992, 23, doi:10.1146/annurev.es.23.110192.000513.

181. Ellison, J.C. How South Pacific Mangroves May Respond to Predicted Climate Change and Sea-Level Rise. In; 2000.

182. Ilman, M.; Dargusch, P.; Dart, P.; Onrizal A Historical Analysis of the Drivers of Loss and Degradation of Indonesia's Mangroves. Land Use Policy 2016, 54, doi:10.1016/j.landusepol.2016.03.010.

183. Gandhi, S.; Jones, T. Identifying Mangrove Deforestation Hotspots in South Asia, Southeast Asia and Asia-Pacific. Remote Sensing 2019, 11, 728, doi:10.3390/rs11060728.

184. Lymburner, L.; Bunting, P.; Lucas, R.; Scarth, P.; Alam, I.; Phillips, C.; Ticehurst, C.; Held, A. Mapping the Multi-Decadal Mangrove Dynamics of the Australian Coastline. Remote Sensing of Environment 2020, 238, doi:10.1016/j.rse.2019.05.004. 
185. Woodroffe, C.D.; Thom, B.G.; Chappell, J. Development of Widespread Mangrove Swamps in Mid-Holocene Times in Northern Australia. Nature 1985, 317, doi:10.1038/317711a0.

186. Gilman, E.L.; Ellison, J.; Duke, N.C.; Field, C. Threats to Mangroves from Climate Change and Adaptation Options. Aquatic Botany 2008.

187. Hamilton, L.S.; Snedaker, S.C. Handbook for Mangrove Area Management; 1984;

188. Thu, P.M.; Populus, J. Status and Changes of Mangrove Forest in Mekong Delta: Case Study in Tra Vinh, Vietnam. Estuarine, Coastal and Shelf Science 2007, doi:10.1016/j.ecss.2006.08.007. 